\title{
Study of evaluation of groundwater in Gadilam basin using hydrogeochemical and isotope data
}

\author{
Prasanna M.V ${ }^{1,{ }^{*}}$, Chidambaram $\mathrm{S}^{2}$, Shahul Hameed $\mathrm{A}^{3}$, and Srinivasamoorthy $\mathrm{K}^{2}$ \\ 1. School of Engineering and Science, Curtin University of Technology, Sarawak, Miri, Malaysia. \\ 2. Department of Earth Sciences, Annamalai University, Annamalainagar, India. \\ 3. Centre for Water Resources Development and Management, Kozhikode, Kerala, India. \\ *Corresponding author’s email. geoprasanna@gmail.com
}

\begin{abstract}
Gadilam river basin has gained its importance due to the presence of Neyveli Lignite open cast mines and other industrial complexes. It is also due to extensive depressurization of Cuddalore aquifer and bore wells for New Veeranam Scheme is constructed in the downstream of the basin. Geochemical indicators of groundwater were used to identify the chemical processes that control hydrogeochemsitry. Chemical parameters of groundwater such as $\mathrm{pH}$, Electrical Conductivity (EC), Total dissolved solids (TDS), Sodium $\left(\mathrm{Na}^{+}\right)$, Potassium $\left(\mathrm{K}^{+}\right)$, Calcium $\left(\mathrm{Ca}^{+}\right)$, Magnesium $\left(\mathrm{Mg}^{+}\right)$, Bicarbonate $\left(\mathrm{HCO}_{3}{ }^{-}\right)$, Sulphate $\left(\mathrm{SO}_{4}{ }^{-}\right)$, Phosphate $\left(\mathrm{PO}_{4}{ }^{-}\right)$and Silica $\left(\mathrm{H}_{4} \mathrm{SiO}_{4}\right)$ were determined. Interpretation of hydrogeochemical data suggests that leaching of ions followed by weathering and anthropogenic impact controls the chemistry of the groundwater. Isotopic study reveals that recharge from meteoric source in sedimentary terrain and rock water interaction with significant evaporation prevails in hard rock region.
\end{abstract}

Keywords: Groundwater, Water chemistry, Stable Isotopes, Thermodynamic stability, Saturation Index

\section{Introduction}

Groundwater is a natural resource, which is being renewed by different process. Geochemical processes occurring within the groundwater and reactions with dissolved minerals have a profound effect on water quality. Hydrogeochemical composition of groundwater can indicate its origin and history of passage through underground materials, which water has been in contact. 
In Gadilam river basin, groundwater is found in both hard rock and sedimentary terrain and is the most important source of rural/urban drinking water supply (Prasanna 2008). In the recent years due to the advent of industrial growth, large-scale application of synthetic fertilizers for agriculture production and use of pesticides and insecticides for production has caused serious concern regarding susceptibility of groundwater contamination. In addition to this, multivarious human activities particularly those involved in land disposal of industrial effluents and sewage effluents, sludge and solid waste, septic tank effluents, urban run-off and various unknown human activities contaminate groundwater sources.

Gadilam river originates in the hard rock region and flows through the sedimentary terrain. Large scale extraction in this basin is done by Neyveli Lignite Corporation (NLC). The open cast mining of Lignite requires heavy pumping at the rate of $9,000-10,000 \mathrm{~m}^{3} \mathrm{hr}^{-1}$ as water table has to be brought down below the lignite seam (Gowrisankaran 1992). Water from the Veeranam Lake is supplied through transmission line to Chennai city. To augment the supply during failure of monsoon, 48 deep bore wells were drilled and operations are done alternatively to pump the groundwater from deeper aquifer and the pumped water is connected to the New Veeranam Scheme (NVS) pipelines. Apart from these large scale extractions, an industrial estate SIPCOT (Small Industries Promotion Corporation of Tamilnadu) with groups of industries, which generate multi facet chemicals and raw materials are distributed along the downstream of the river Gadilam, near the Cuddalore coast. Aravindan et al. (2004) has attempted to classify the groundwater quality in the hard rock aquifer of Gadilam river basin. A detailed study on sea water intrusion along the Cuddalore (Ramanathan et al. 1999), Chennai (Gnanasundar and Elango 1999 and Satheesh Herbert Singh and Lawrence 2007) and in Pichavaram (Chidambaram et al. 2005) were carried out. Keeping all the above facts in the mind, an attempt has been made to understand the complexity of hydrogeochemical characters in the study area. The entire Gadilam river basin has been selected to have a holistic picture. The main objectives of this study are to understand the hydrogeochemical variation of groundwater with respect to lithology in space and time and probable factors responsible for water chemistry of the region. 


\section{Study area}

Gadilam river basin is located in parts of Cuddalore and Villupuram districts of Tamilnadu, India. It lies in between $79^{\circ} 0^{\prime} \mathrm{E}$ to $79^{\circ} 47^{\prime} \mathrm{E}$ longitudes and $11^{\circ} 30^{\prime} \mathrm{N}$ to $11^{\circ} 55^{\prime} \mathrm{N}$ latitudes (Fig. 1). It occurs within the Survey of India toposheets of 58M/1, 2, 5, 6, 9, 13, 10 and 14, covering a total area of about 1,394 sq.km. The Gadilam river basin is bounded by Ponnaiyar river basin in the North and the Vellar river basin in the south. The total length of the river is about $112 \mathrm{~km}$ with a catchment area extending about 900 sq.km. The average annual rainfall of the basin is about $1643 \mathrm{~mm}$. The water level ranges from $3.10 \mathrm{mbgl}$ to $98.85 \mathrm{mbgl}$ (below ground level) with an average of $62.37 \mathrm{bgl}$. The river basin has different rock types along its flow path. The lithological set up of the basin shows that hard basement rocks are exposed in western part of the study area and sedimentary formation in the east with a faulted contact between both (Aravindan et al. 2004). River originates in the hard rock region and flows through the sedimentary terrain. The basin covers different stratigraphic units viz. Archaean, Cretaceous and Tertiary to Recent alluvium (Fig. 2). The charnockites, granites, syenites and gneiss of archaean complex constitute the upstream area. The younger cretaceous and tertiary formations are found in the midstream and recent alluvium in the downstream of the Gadilam river basin. Lithologically, hard rocks constitute the western part of the basin. In the sedimentary region, northern part essentially comprises of recent alluvium and the rest by sandstone.

\section{Materials and Methods}

The water samples were collected during March 2005, July 2005, November 2006, and January 2006 to broadly cover all seasons (Fig. 2). A total of 178 water samples were collected from 156 bore wells, river (14) and tank (8) in four different seasons (November 2006 represents NE monsoon; January 2006 represents Post monsoon; March 2005 represents Summer; July 2005 represents SW monsoon). In summer (SUM) and south west monsoon (SWM), twelve groundwater samples were collected from Alluvium, ten samples from Tertiary, fourteen samples from Archaean and two surface water from tank. In north east monsoon (NEM) and post monsoon (POM), twelve groundwater samples were collected from Alluvium, twelve samples from Tertiary, seventeen groundwater samples from Archaean, one groundwater 
sample from Cretaceous, seven surface water from river and two surface water from tank. Cretaceous formation covers less than $5 \%$ of the study area. In certain location during summer and southwest monsoon periods the wells were dry. River Gadilam is an ephemeral river with water flows only during NEM and POM periods.

One litre of water samples was collected in polyethylene bottle four times a year to broadly cover seasonal variation with respect to lithology. Then it was sealed and brought to laboratory for analysis and stored at $4^{\circ} \mathrm{C}$ before analysis.

The samples collected were analyzed for major cations like, Ca and Mg by Titrimetry, Na and K by Flame photometer (CL 378); anions, $\mathrm{Cl}$ and $\mathrm{HCO}_{3}$ by Titrimetry, $\mathrm{SO}_{4}, \mathrm{PO}_{4}$, and $\mathrm{H}_{4} \mathrm{SiO}_{4}$ by Spectrophotometer (SL 171 minispec). EC and pH were determined in the field using electrode (Eutech). The analyses were done by adopting standard procedures (APHA 1998).

Stable Isotopic studies $\left(\delta^{18} \mathrm{O}\right.$ and $\left.\delta \mathrm{D}\right)$ were carried out for 60 samples from different locations of Gadilam river basin during south west monsoon (2005) and post monsoon (2006) following standard procedures of International Atomic Energy Agency (IAEA). Isotopic studies were done for groundwater, surface water and rain water samples. Oxygen $\left(\delta^{18} \mathrm{O}\right)$ and Deuterium $(\delta \mathrm{D})$ present in samples were analyzed by using Isotopic Ratio Mass Spectrophotometer (Finnigan Delta ${ }^{\text {plus }} \mathrm{Xp}$, Thermo Electron Corporation, Bermen, Germany, the standard deviation of our measurements is $\pm 1.72 \%$ for Oxygen and $\pm 0.8 \%$ o for Hydrogen) . All the measurements were carried out against laboratory substandard that were periodically calibrated against the international isotope water standards recommended by the IAEA (VSMOW). The isotope results obtained are reported in terms of $\delta$ units (permil deviation of the isotope ratio from the international standard V-SMOW) $\delta$ being defined by

$$
\begin{aligned}
& \delta=\left(\mathrm{R}_{\text {sample }}-\mathrm{R}_{\text {SMOw }} / \mathrm{R}_{\text {sMow }}\right) \times 10^{3} \\
& \text { where, } \mathrm{R}=\mathrm{D} / \mathrm{H} \text { or }{ }^{18} \mathrm{O} /{ }^{16} \mathrm{O}
\end{aligned}
$$




\section{Result and discussion}

\subsection{Water chemistry}

The average, mean, and standard deviation values of the water samples collected during four different seasons in different formations are given in Table 1a and 1b. The total cations $\left(\mathrm{TZ}^{+}\right)$and total anion (TZ') balance (Freeze and Cherry 1979) is considered to shows the charge balance error percentage. The error percentage in the samples of the present study ranges between $\pm 1 \%$ to $\pm 10 \%$. Occurrence of errors in chemical analysis of groundwater is also due to the reagents employed, limitations of the methods and the instruments used, presence of impurities in distilled water etc. The correlation coefficient between $\mathrm{TZ}^{+}$and $\mathrm{TZ}^{-}$is around 0.6 to 0.9 . TDS / EC ratio was ranging from 0.5 to 0.9 . The role played by other ions than those considered here for the cations and anions charge balance is less significant.

In Alluvium formation, $\mathrm{Cl}$ is the dominant anion followed by $\mathrm{HCO}_{3}, \mathrm{SO}_{4}$ and $\mathrm{PO} 4$ during $\mathrm{SUM}$, NEM and POM seasons. But in $\mathrm{SWM}, \mathrm{HCO}_{3}$ is the dominant anion followed by $\mathrm{Cl}, \mathrm{SO}_{4}$ and $\mathrm{PO}_{4}$. Higher concentration of chloride in this region is may be due to sea water intrusion along the coast (Chidambaram et al. 2007). In POM, Na is the dominant cation followed by Ca, K and Mg. But in SUM, SWM and NEM, $\mathrm{Na}$ is the dominant cation followed by $\mathrm{Ca}, \mathrm{Mg}$ and $\mathrm{K}$. Na is found to be the dominant cation it may be due to the weathering of Alkali feldspar in rocks or due to cationic contribution from sea water.

In Tertiary Formation, $\mathrm{Cl}$ is the dominant anion followed by $\mathrm{SO}_{4}, \mathrm{HCO}_{3}$ and $\mathrm{PO}_{4}$ during SUM. In $\mathrm{POM}, \mathrm{Cl}$ is the dominant anion followed by $\mathrm{HCO}_{3}, \mathrm{SO}_{4}$ and $\mathrm{PO}_{4}$. In $\mathrm{SWM}, \mathrm{HCO}_{3}$ is the dominant anion followed by $\mathrm{SO}_{4}, \mathrm{Cl}$ and $\mathrm{PO}_{4}$. In NEM, $\mathrm{HCO}_{3}$ is the dominant anion followed by $\mathrm{Cl}, \mathrm{SO}_{4}$ and $\mathrm{PO}_{4}$. The contribution of $\mathrm{HCO}_{3}^{-}$is may be due to chemical weathering of silicate and carbonate minerals (Srinivasamoorthy 2004). In SUM, NEM and POM, Na is the dominant cation followed by Ca, K and Mg. But in SWM, Na is the dominant cation followed by $\mathrm{Ca}, \mathrm{Mg}$ and $\mathrm{K}$.

In Archaean formation, $\mathrm{HCO}_{3}$ is the dominant anion followed by $\mathrm{Cl}, \mathrm{SO}_{4}$ and $\mathrm{PO}_{4}$ during $\mathrm{SUM}$, SWM and NEM seasons. But in $\mathrm{POM}, \mathrm{Cl}$ is the dominant anion followed by $\mathrm{HCO}_{3}, \mathrm{SO}_{4}$ and $\mathrm{PO}_{4}$. The contribution of chloride may be due to the leaching of secondary salts during weathering processes. In 
SUM, SWM and POM, Na is the dominant cation followed by Ca, K and Mg. But in NEM, Na is the dominant cation followed by Ca, Mg and K.

In tank water, $\mathrm{Cl}$ is the dominat anion followed by $\mathrm{HCO}_{3}, \mathrm{SO}_{4}$ and $\mathrm{PO}_{4}$ irrespetive of seasons. $\mathrm{Na}$ is the dominant cation followed by $\mathrm{Ca}, \mathrm{K}$ and $\mathrm{Mg}$ irrespective of seasons. In river water, $\mathrm{HCO}_{3}$ is the dominant anion followed by $\mathrm{Cl}, \mathrm{SO}_{4}$ and $\mathrm{PO}_{4}$ irrespective of seasons. In $\mathrm{NEM}$, $\mathrm{Na}$ is the dominant cation followed by Ca, Mg and K. But in POM, Na is the dominant cation followed by Ca, K and Mg.

\subsection{Geochemical classification}

Hydrogeochemical facies interpretation is a useful tool for determining the flow pattern, origin of chemical histories of groundwater. The diamond field of Piper (1944) for Alluvium formation (Fig. 3) shows variation with seasons. The plot mainly falls in fields 2, 3, 4 and 1. In NEM and POM, the samples are concentrated in Na-Cl type indicating saline nature in the groundwater. In SUM and SWM, cluster of samples fall in $\mathrm{Na}-\mathrm{Cl}$ and mixed $\mathrm{Ca}-\mathrm{Na}-\mathrm{HCO}_{3}, \mathrm{Ca}-\mathrm{Mg}-\mathrm{Cl}$ facies. The data plot of Piper Trilinear diagram

(Fig. 3) indicates the change of $\mathrm{CaHCO}_{3}$ facies in summer to $\mathrm{NaCl}$ facies in winter, as calcium is replaced by sodium during North East monsoon (Aravindan et al. 2004). In Tertiary formation (Fig. 4), the plot falls in fields 2, 3, 4 and 5. The dominant fields are 2, 3 and 4. SUM and SWM seasons are well represented in plot 2 and 3, indicating the dominance of alkaline and strong acids. In NEM and POM, cluster of samples fall in Na-Cl type and some samples also represent mixed Ca-Mg-Cl and $\mathrm{Ca}-\mathrm{Cl}$ facies.

In Archaean (Fig. 5), most of the plots fall in field 2 with less representation in 3 and 4. In NEM and POM, alkaline and strong acid are predominant indicating the intensive weathering action of silicate bearing minerals and secondary leaching of ions (Srinivasamoorthy 2004). In SUM and SWM, majority of samples fall in $\mathrm{Na}-\mathrm{Cl}$ and mixed $\mathrm{Ca}-\mathrm{Mg}-\mathrm{Cl}$ with minor representation from mixed Ca-Na-HCO 3 and Ca$\mathrm{HCO}_{3}$ facies.

In Cretaceous formation (Fig. 6), NEM samples fall in $\mathrm{Ca}-\mathrm{HCO}_{3}$ facies indicating the dominant of alkali earth and week acids. But in POM, plot fall in $\mathrm{Na}-\mathrm{Cl}$ facies indicating the predominant of alkaline and strong acid. In tank waters (Fig. 7), SUM and SWM samples fall in Na-Cl and mixed Ca-Mg-Cl facies. 
In NEM and POM, most of the samples fall in $\mathrm{Na}-\mathrm{Cl}$ facies indicating the dilution of secondary salt precipitation. In river water (Fig. 7), cluster of samples during POM is noted in Na-Cl facies and NEM samples fall in mixed Ca-Na- $\mathrm{HCO}_{3}, \mathrm{Ca}-\mathrm{HCO}_{3}$ and mixed Ca-Mg-Cl facies. In general, the plot shows that alkali $(\mathrm{Na})$ exceeds alkaline earth $(\mathrm{Ca}$ and $\mathrm{Mg})$ and strong acid $\mathrm{Cl}$ and $\mathrm{SO}_{4}$ exceeds the week acids $\left(\mathrm{HCO}_{3}\right)$ in all the litho units irrespective of season.

\subsection{Ionic Strength}

Ionic strength is a measure of total concentration of ions which emphasizes increased contribution of species with charges greater than one to solution non-ideality (Domenico and Schwartz 1990).

$$
\mathrm{I}=0.5 \sum \mathrm{m}_{1} \mathrm{z}_{1}^{2}
$$

Where $\mathrm{m}_{1}$ is the atomic/molecular weight and $\mathrm{z}_{1}$ is the valance of the respective ion. Ionic strength of fresh water is less than 0.005 (Hem 1959). In the study area, higher ionic strength was noted in Alluvium and Archaean formation irrespective of seasons, indicating lesser inflow of fresh water into the system (Fig. 8). Low ionic strength was noted in Tertiary formation indicating higher inflow of fresh water/ recharge (Prasanna et al. 2006).

\subsection{Partial pressure of Carbon dioxide $\left(\mathrm{PCO}_{2}\right)$}

In SUM, the $\operatorname{LogPco}_{2}$ values ranges from -2.5 to -1 . The samples from Tertiary formation and certain samples in Alluvial terrain show nearly the atmospheric value (-3.5) (Fig. 9). Samples from Archaean formation show higher $\mathrm{PcO}_{2}$ value ranging from -2.39 to -1.19 suggesting that the additional $\mathrm{CO}_{2}$ has been acquired from the soils during the process of infiltration towards the zone of saturation (Prasanna et al. 2006). In SWM, certain samples in Alluvium and Tertiary formations show nearly similar or slightly lesser than the atmospheric $\log \mathrm{PCO}_{2}$ values. It may be interpreted that their residence time in the aquifer

matrix is considerably lesser. Higher $\mathrm{Log} \mathrm{PCO}_{2}$ values are noted in Archaean formation. In NEM, all the samples irrespective of terrains, show higher $\log \mathrm{PcO}_{2}$ value except few representations of near 
atmospheric $\log \mathrm{PCO}_{2}$. In POM, majority of samples irrespective of terrains fall around the atmospheric Log $\mathrm{PCO}_{2}$ value indicating recent recharge waters by the monsoon rainfall.

\subsection{Thermodynamic stability}

Thermodynamic plotting of $\left[\mathrm{Na}^{+}\right] / \mathrm{H}^{+},\left[\mathrm{K}^{+}\right] / \mathrm{H}^{+},\left[\mathrm{Ca}^{2+}\right] / \mathrm{H}^{+}$and $\left[\mathrm{Mg}^{2+}\right] / \mathrm{H}^{+}$, for the groundwater in major litho units in the study area are plotted on the stability diagram (Fig. 10-14) as a function of $\left[\mathrm{H}_{4} \mathrm{SiO}_{4}\right]$.

\subsubsection{Na system}

In Alluvium formation (Fig. 10), samples fall in the Kaolinite stability field during SUM and SWM seasons indicating incongruent dissolution of Na- feldspar to produce Kaolinite and dissolved products. As dissolution of feldspar continues the values of $\mathrm{Si}(\mathrm{OH})_{4}$ and $\left(\mathrm{Na}^{+}\right) /\left(\mathrm{H}^{+}\right)$increases and water chemistry moves to Na-Montmorllonite during NEM and POM. In Tertiary formation (Fig. 11), SUM, SWM and NEM samples fall in Kaolinite field and it moves towards Na-Montmorllonite field in POM season. Hence the formation of new clay minerals in the area is expected due to supply of excess cation and Silica to the pre-existing Kaolinite, which appears to be formed owing to evaporation processes as suggested by Jacks (1973).

In Archaean (Fig. 12), same trend was observed as in Alluvium. In Cretaceous (Figure 13), samples fall in the Kaolinite field irrespective of seasons. In surface water (Fig. 14), samples fall in the Kaolinite field irrespective of seasons and the river water samples move towards Na-Montmorllinite field during POM may be due to concentration of ions along flow path of water. Generally, samples of SUM and SWM are stable in Kaolinite field, whereas in NEM and POM samples are moves towards NaMontmorllonite field.

\subsubsection{K system}

In Alluvium (Fig. 10), majority of SWM, SUM and NEM seasons sample falls in Kaolinite field and most of the POM samples fall in Muscovite and K-Feldspar fields. Minor representation of NEM and SWM seasons sample are also noted in Muscovite field. The diagram delineates stability field of clay 
minerals that co-exist in sediment phase at a constant composition of water during chemical reaction of rock and water. It is evident that formation of Kaolinite and Muscovite has released silica and hence $\mathrm{H}_{4} \mathrm{SiO}_{4}$ has increased in groundwater. Similar trend was observed in Tertiary, Archaean and Cretaceous formations (Fig. 11, 12 and 13) as in Alluvium with fewer representations of SWM and SUM samples move towards Muscovite field. In surface waters (Fig. 14) irrespective of seasons, plot moves from Kaolinite to Muscovite and K-Feldspar fields. Generally samples of SUM, SWM and NEM are stable in Kaolinite field, whereas in POM samples are stable in Muscovite and K-Feldspar fields.

\subsubsection{Ca-system}

In Alluvium (Fig. 10), the plot shows that migration from Kaolinite to Ca-Montmorllinite field in NEM and POM seasons. Most of the samples in SUM, SWM and NEM fall in Kaolinite field may be due to the removal of Ca from the system by the precipitation of Ca salts. Similar trend was observed in Tertiary and Archaean formations (Fig. 11 and 12). In Cretaceous (Fig. 13), shift of stability from Kaolinite in POM to Ca-Montmorllinite in NEM season was noted due to the increase of silica and Ca ion in the groundwater. In surface waters (Fig. 14), the samples irrespective of season move from Kaolinite to Montmorllinite field.

\subsubsection{Mg-system}

In Alluvium (Fig. 10), the samples of SUM, SWM and NEM are stable with Kaolinite field and due to the increase of $\mathrm{Mg}$ and $\mathrm{H}_{4} \mathrm{SiO}_{4}$, samples fall in Chlorite stability field during POM. Seasonal variations indicates shift of samples between two fields Kaolinite and Chlorite due to forward or reverse nature of reaction.

Chlorite $+10 \mathrm{H}^{+}=$Kaolinite $+5 \mathrm{Mg}^{2+}+\mathrm{H}_{4} \mathrm{SiO}_{4}+5 \mathrm{H}_{2} \mathrm{O}$

Same trend was observed in Tertiary and Cretaceous (Fig. 11 and 13). In Archaean (Fig. 12), NEM and POM samples moves towards Chlorite field due to the excess supply of cation and Silica. In 
Surface waters (Fig. 14), samples irrespective of seasons show shift in composition from Kaolinite to Chlorite field.

\subsection{Factor Analysis}

In SUM, 3 factors were extracted with $78.62 \%$ of Total data variability (TDV) (Table 2). Factor I was represented by $\mathrm{Cl}^{-}, \mathrm{HCO}_{3}$, Ca Mg and $\mathrm{Na}$ indicating leaching of secondary salts. The concentration of $\mathrm{Na}$ and $\mathrm{Cl}$ can be ascribed to the intrusion of seawater into the aquifer system which increases the concentrations of these ions. The presence of $\mathrm{HCO}_{3}, \mathrm{Ca}$ and $\mathrm{Mg}$ reflects the signatures of natural water recharge and rock-water interaction. Surface water charged with atmospheric and biogenic $\mathrm{CO}_{2}$ infiltrates into the subsurface and aggressively attack aluminosilicates including feldspars and micas present in the formation liberating cations such as $\mathrm{Ca}$ and $\mathrm{Mg}$ into the water and leaving residues of clay minerals. As a consequence of this incongruent dissolution, there is a rise in $\mathrm{pH}$ and in $\mathrm{HCO}_{3}$ concentration of the water (Freeze and Cherry 1979). Factor 2 represented by $\mathrm{PO}_{4}$ and $\mathrm{K}$ indicating the anthropogenic impacts from the agricultural practices. Factor 3 represented by $\mathrm{HCO}_{3}$ and $\mathrm{Ca}$ indicating water-soil/rock interaction.

In SWM, 3 factors were extracted with $76.90 \%$ of Total data variability (TDV). Factor 1 was represented by $\mathrm{Cl}, \mathrm{HCO}_{3}$, Ca and Na, which is similar to factor 1 in SUM (Table 2). Factor 2 representing $\mathrm{PO}_{4}, \mathrm{H}_{4} \mathrm{SiO}_{4}$, Ca and $\mathrm{Mg}$ indicating anthropogenic impact from the agricultural practices (Chidambaram et al. 2008). Factor 3 represented by $\mathrm{SO}_{4}$ and $\mathrm{K}$ also indicating anthropogenic impact.

In NEM (Table 2), 3 factors were extracted with 73.96\% of Total data variability (TDV). Factor 1 representing $\mathrm{Cl}, \mathrm{Ca}, \mathrm{Mg}$ and $\mathrm{Na}$ indicating leaching of secondary salts. Factor 2 representing $\mathrm{HCO}_{3}, \mathrm{SO}_{4}$, $\mathrm{Na}$ and $\mathrm{K}$ indicating intensive weathering. Factor 3 represented by $\mathrm{PO}_{4}$ and $\mathrm{H}_{4} \mathrm{SiO}_{4}$ indicating anthropogenic impacts from the agricultural practices.

In POM (Table 2), 3 factors were extracted with 77\% of Total data variability (TDV). Factor 1 represented by $\mathrm{Cl}, \mathrm{Ca} . \mathrm{Mg}$ and $\mathrm{Na}$ follow the same trend of factor 1 in NEM. Factor 2 represented by $\mathrm{SO}_{4}$, $\mathrm{PO}_{4}$ and $\mathrm{K}$ indicating anthropogenic impacts from fertilizers. Factor 3 represented by $\mathrm{HCO}_{3}$ and $\mathrm{H}_{4} \mathrm{SiO}_{4}$ indicating weathering of silicate minerals. 
In general leaching of secondary salts, weathering and anthropogenic impacts are the dominant controlling factors governing the groundwater in the study area.

\subsection{Isotopic signatures}

\subsubsection{Isotopic ratio in south west monsoon}

Totally 19 samples (groundwater and surface water) were collected and analyzed for stable isotopes oxygen-18 and Deuterium in September 2005 (Table 3). It is observed that there is a clear demarcation of isotopic signatures in ground water of different terrains in the study area (Fig. 15). The isotope ratios of oxygen and hydrogen are higher in Archaean followed by Alluvium and Tertiary. The $\delta \mathrm{D}$ and $\delta^{18} \mathrm{O}$ data provides information on the secondary processes acting in the water as it travels into the subsurface. The collected groundwater samples of Tertiary formation have a range from $-7.95 \%$ to $-6.25 \%$ o for $\delta^{18} \mathrm{O}$ and from $-52.85 \%$ to $-45.93 \%$ for $\delta \mathrm{D}$. The mean isotope values of groundwater are $-7.33 \%$ and $50.90 \%$ for $\delta^{18} \mathrm{O}$ and $\delta \mathrm{D}$ respectively. The $\delta \mathrm{D}$ and $\delta^{18} \mathrm{O}$ values of the groundwater samples fall nearer to Local meteoric water line (LMWL) indicating recharge from meteoric source (Prasanna et al. 2007).

The ground water has slightly less $\delta^{18} \mathrm{O}$ and $\delta \mathrm{D}$ than the weighted mean for precipitation (Ian Clark and Peter Fritz 1997). Minor deviation from the weighted average precipitation can also be attributed to the land use practices. Darling and Bath (1988) noted that recharge beneath permanent grass cover is somewhat isotopically depleted relative to the favorable plots, reflecting the evaporation loss, which may also be contributory factors for major isotopic variation from Global meteoric water line (GMWL).

The groundwater samples belong to Alluvium formation have a range from $-7.19 \%$ to $-6.17 \%$ for $\delta^{18} \mathrm{O}$ and from $-50.49 \%$ to $-44.63 \%$ for $\delta \mathrm{D}$. The mean isotope values of groundwater are $-6.85 \%$ and $-48.33 \%$ for $\delta^{18} \mathrm{O}$ and $\delta \mathrm{D}$ respectively. Groundwater samples of this formation fall parallel to the LMWL or GMWL indicating recharge has taken place by the local precipitation (Chidambaram et al. 2007). Allison et al. (1984) developed a concept that under certain conditions of direct infiltration often has an ${ }^{18} \mathrm{O}-{ }^{2} \mathrm{H}$ composition that plots parallel to the local meteoritic water line. It is because of the mixing that occurs between the evaporated soil moisture and subsequent rain that infiltrates and displaces the residual 
soil water downwards, this mixture ultimately reaches the water table. Since the Alluvial formation are porous and permeable, easy infiltration of rain water is depicted in the isotopic ratios.

The groundwater samples belonging to Archaean formation have a range from $-5.7 \%$ o to $-4.12 \%$ o for $\delta^{18} \mathrm{O}$ and from $-43.32 \%$ to $-38.39 \%$ for $\delta \mathrm{D}$. The mean isotope values of groundwater are $-4.96 \%$ and 41.66\% for $\delta^{18} \mathrm{O}$ and $\delta \mathrm{D}$ respectively. In Archaean formation, enrichment of heavier isotopes is noted may be due to two factors. 1) The samples are displaced from the LMWL, this may be because of the extensive evaporation form the unsaturated zone. 2) Kinetics effect by vapour diffusion is greater than those associated with evaporation from open surfaces (Ian Clark and Peter Fritz 1997). The slope of $\delta^{18} \mathrm{O}-\delta^{2} \mathrm{H}$ relation was only $\sim 2$, much lower than the range for the evaporation from the open water surfaces. Hence, either one of the above two factors or in combinations may be the responsible for low slope. This displacement may also be due to recharge of the evaporated surface waters. Since few surface water tanks are located in the hard rock terrains of the study area, these tanks may significantly contribute water to the ground system. The evaporation taking place in the fractures is also well witnessed by the higher saturation index (S.I) of Calcite, precipitation of Calcite is also witnessed in the fractures along the well cuttings of the study area (Chidambaram et al. 2007) (Fig. 21). Though few rock water interaction mechanisms are also noted in this terrain. $\delta \mathrm{D}$ and $\delta^{18} \mathrm{O}$ values of the surface water samples fall away from the GMWL line indicating that the waters are mostly affected by evaporation processes.

\subsubsection{Isotopic ratio in post monsoon}

Totally 41 samples (groundwater and surface water) were collected and analyzed for stable isotopes oxygen-18 and Deuterium in January 2006 (Table 4). The $\delta \mathrm{D}$ and $\delta^{18} \mathrm{O}$ data fall into distinct groups providing information on the secondary processes acting on the water as it travel from precipitation to groundwater. The river water samples plot to the right of the LMWL along a shallow-slopping trend, suggesting a typical evaporation pattern (Fig. 16). The groundwaters in Tertiary formation fall within a cluster either close to or to the right of the LMWL, indicating that these samples have undergone some evaporation prior to infiltration (Baskaran et al. 2005). In Alluvium formation, samples fall parallel to the LMWL indicating recharged by the local precipitation. The majority of Archaean terrain groundwaters plot 
along a shallow-slopping trend to the right of the LMWL, indicating that evaporation concentration is a significant process for these samples.

The $\delta \mathrm{D}$ and $\delta^{18} \mathrm{O}$ composition for the groundwater in the downstream of the river basin are different from the isotopic composition of the groundwater in the upstream of the basin. Majority of groundwater samples in the downstream have a relatively depleted isotopic signature (high negative values) that is similar to certain river water samples. This indicates that infiltrating river water or evaporated river recharge is the source for the groundwater in the downstream during this season. Under low or average flow condition, river water tends to be isotopically enriched relative to rainfall because of surface water evaporation (Simpson and Herczeg 1991).

\subsubsection{SDeuterium Vs. Chloride}

A comparison of the deuterium and chloride data provides greater understanding of groundwatersurface water interaction processes in the study area. There is a significant variation of isotopic characters with respect to $\mathrm{Cl}$ in the formations during SWM. In general, Tertiary has lower $\delta \mathrm{D}$ and $\mathrm{Cl}$ values it gradually increases in Alluvium and there is a notable increase of both in the Archaean formation indicating the higher residence time and enrichment of $\mathrm{Cl}$ ions. The chloride-deuterium plot suggests that two types of groundwater occur in the study area (Fig. 17) namely: (i) groundwater samples from the downstream side of the basin (Alluvium and Tertiary formations), characterized by low chloride and depleted D, (except in Karaikadu location shows higher concentration of chloride due to anthropogenic activity nearby the industry) which represent areas that are recharged frequently by rainfall (Baskaran et al. 2005). (ii) groundwater samples in the upstream side of the basin (Archaean formation) with high chloride and enriched D, indicates less recharge from meteoric water and recharge of the evaporated waters from different source nearby may be due to the evaporation taking place along the fractures. Higher concentration of chloride was attributed by the leaching of secondary salts from the formation (Chidambaram et al. 2007). 
It has been reported that recharge by surface water via bank infiltration would be characterized by low chloride and relatively enriched $\delta \mathrm{D}$ signatures whereas diffuse recharge would tend to be enriched in chloride and depleted in $\delta \mathrm{D}$ (Lamontagne et al. 2002). In POM, chloride-deuterium plot suggests that three types of groundwaters occur in the study area (Fig. 18) namely; (1) Majority of groundwaters from sedimentary terrain (both Tertiary and Alluvium) with low $\mathrm{Cl}^{-}$and depleted deuterium, representing that are recharged more frequently by local rainfall and less frequently by river water. (2) Some groundwater samples from Archaean terrain characterized by low $\mathrm{Cl}^{-}$and relatively enriched by deuterium that is frequently recharged by river waters. (3) Certain groundwater samples in Archaean and Alluvium formations, with very high $\mathrm{Cl}^{-}$and lower deuterium is due to the diffusive recharge along the flow path. This indicates rarely that it receives recharge from surface water (Baskaran et al. 2005).

\subsection{4. $\log \mathrm{PCO}_{2}$ VS. $\delta^{18} \mathrm{O}$ and $\delta D$}

During SWM (Fig. 19), $\mathrm{LogPCO}_{2}$ values of the region range from -2.41 to -0.98 . These values are higher in comparison to the average atmospheric $\mathrm{Pco}_{2}$ value of -3.5 atm (Wigley 1973; Raymahashay 1986). The $\operatorname{LogPCO}_{2}-\delta^{18} \mathrm{O}$ plot suggest that majority of groundwater samples from the sedimentary formation (Alluvium and Tertiary formations) characterized by low $\mathrm{Pco}_{2}$ values and depleted $\delta^{18} \mathrm{O}$ indicating recent recharge by the local precipitation. Groundwater samples from the hard rock region (Archaean formation) with higher $\mathrm{Pco}_{2}$ values and enriched $\delta^{18} \mathrm{O}$ indicates long residence time. This also suggest that the rainwater charged with atmospheric $\mathrm{CO}_{2}$ has acquired additional $\mathrm{CO}_{2}$ from the soils and thereby developing high $\mathrm{Pco}_{2}$ water on their travel to deep unsaturated zone (Prasanna et al. 2007). In POM (Fig. 20), $\mathrm{LogPCO}_{2}$ values of the region range from -4.00 to -1.62 respectively. The $\mathrm{LogPco}_{2}-\delta \mathrm{D}$ plot follows the similar trend as in SWM.

\subsection{Saturation State}

The disequilibrium indices of Carbonate minerals Aragonite, Calcite, Dolomite, Magnesite and Hydromagnesite were represented from the data bank of WATEQ4F and studied for the dissociation factors in the major litho units of the study area. The Fig. 21, 22 and 23 shows the indices of saturation of 
Carbonate bearing minerals in the groundwater. The samples in Alluvium are in equilibrium state with Aragonite and Calcite in SUM and NEM, Dolomite and Magnasite show under saturation to saturation state (Fig. 21). In SWM, Calcite and Aragonite fall in saturation to over saturation state and the Dolomite and Magnasite is under saturated to near saturation state. This indicates the effect of dilution in monsoon period. In POM, majority of carbonate minerals show saturation to over saturation state with minor representation in under saturation state. Generally Fluctuations of saturation index of calcite (S.I $\left.\mathrm{I}_{\mathrm{C}}\right)$ along the line of saturation in different seasons are also noted. In Tertiary formation (Fig. 22) majority of carbonates minerals show under saturation state with minor representation of Calcite and Aragonite in near saturation line during SUM, SWM and NEM. This may be due to the lesser mobility of ions during this period, which reduces S.Ic.

During POM, Carbonate minerals show saturation state with minor locations representing under saturation state. In Archaean formation (Fig. 23), Calcite and Aragonite show saturation to over saturation state. During POM, all the Carbonate minerals show over saturation state indicating the effect of precipitation after monsoon period. In general, $\mathrm{CO}_{3}$ results shows that Calcite and Aragonite are saturated to oversaturated state.

The lower values of $\mathrm{SI}_{\mathrm{c}}$ are compared to saturation index of Dolomite $\left(\mathrm{SI}_{\mathrm{d}}\right)$ in POM season, this may be due to the result of $\mathrm{Ca}^{2+}$ precipitation (Atkinson 1983) or because of equilibrium with Calcite after Dolomite. The mechanism involved in the breaking down of feldspars and dissolution and precipitation of Calcite is governed by the system $\mathrm{CaCO}_{3}-\mathrm{CO}_{2}{ }^{2-}-\mathrm{H}_{2} \mathrm{O}$ (Berner, 1974). The degassing possibly occurs more rapidly leading to super saturation of groundwater with respect to Calcite (Pawar 1985). Field evidences suggest that $\mathrm{CO}_{2}^{2-}$ has diffused along the joints, cracks and fissures in the hard rock terrain resulting in the deposition of secondary Carbonates (Calcite). Dolomite however, does precipitate due to kinetic constrains (Wigley 1976). In general Carbonate minerals except Magnesite are in equilibrium state with the groundwater indicating the capability of heavy scale formation by equilibrium of Calcite, Aragonite and Magnesite. 


\subsubsection{Saturation index of Calcite vs. $\delta^{18} \mathrm{O}$}

During SWM period (Fig. 24), the SI of Calcite and $\delta^{18} \mathrm{O}$ form a linear relationship represented three different categories. The SI of Calcite ranges from -2.09 to 0.52. Higher values are noted in the Archaean formation whereas the lower values are in the Tertiary formation. The SI of Calcite vs $\delta^{18} \mathrm{O}$ plot suggests that the groundwater samples from Archaean formation fall in over saturation state indicates evaporation taking place along the fractures. Groundwater samples from the Tertiary formation shows under saturation indicate that the area is recharged frequently by rainfall. Groundwater samples from the Alluvium formation fall from under saturation to saturation state.

During POM (Fig. 25), the SI of Calcite ranges from -0.65 to 1.89. Higher values are noted in the Archaean and Alluvium formations whereas the lower values are in the Tertiary formation. The SI of Calcite vs $\delta \mathrm{D}$ plot suggests that the groundwater samples from Archaean formation shows enriched deuterium with higher saturation index fall in over saturation state indicates evaporation concentration is a significant process for these samples.

Groundwater samples from the Tertiary formation shows depleted deuterium with lesser saturation index fall in under saturation zone indicates dilution by rainfall/river water. Groundwater samples from the Alluvium formation shows depleted deuterium with higher saturation index indicates leaching of dissolved salts.

\section{Conclusion}

The chemical composition of groundwater in the Gadilam river basin shows dominant facies in the entire litho unit is $\mathrm{Na}-\mathrm{Cl}$ type indicating saline nature in the groundwater. The thermodynamic state of stability varies with respect to lithology, but majority of the samples are stable with Kaolinite field with shift in stability due to the availability of silica and cations in the groundwater system. The availability of ions in different formations is governed by seasons. The study indicates that the groundwater of the alluvium and the Archaean formations have higher ion concentration irrespective of season. The statistical analysis carried out to unravel the factors responsible for the variation in the water chemistry with season indicates that the secondary leaching of salts, weathering and anthropogenic activities play a major role. Isotopic study reveals that recharge from meteoric source in sedimentary terrain and rock water interaction 
with significant evaporation prevails in hard rock area. The impact of monsoon is well witnessed in the sedimentary formations than the Archaean. Understanding the above process helps us to make a judicious usage of this resource and to maintain its quality.

\section{Acknowledgement}

The authors wish to express thank to Department of Science and Technology, India for provided the necessary financial support to carry out this study. They are also thankful to Centre for Water Resource, Development and Management (CWRDM), Kozhikode, India for helping in the stable isotope analysis of the water samples.

\section{References}

Allison, G.B., Barnes, C.J., Hughes, M.W., \& Leaney, F.WJ. (1984). Effect of climate and vegetation on oxygen-18 and deuterium profiles in soils. In: Isotope Hydrology 1983, IAEA Symposium 270, September 1983, Vienna, 105-123.

APHA (1998). Standard methods for the examination of water and wastewater. $19^{\text {th }}$ edition, APHA, Washington DC, USASS.

Aravindan, S., Manivel, M., \& Chandrasekar, S.V.N. (2004). Groundwater quality in the hard rock area of the Gadilam river basin, Tamilnadu. Journal of Geological Society of India, 63, 625-635.

Atkinson, TC. (1983). Growth mechanism of spelotherms in castleguard cave, Colombia ice fields, Alberta, Canada. Artic and Alpine Research, 15(4), 523-536.

Baskaran, S., Ransley, T., Brodie, R.S., \& Baker, P. (2005). Investigating groundwater River interactions using Environmental Tracers. Bureau of Rural Sciences, Canberra.

Berner, RA. (1974). Kinetic models for the early diagenesis of nitrogen, sulfur, phosphorous and silicon in anoxic marine sediments. The Sea, v.5, d. E.D.Goldberg. Wiley Interscience, New York, 427-450.

Chidambaram, S., Prasanna, M.V., Vasu, K., Shahul Hameed, A., Unnikrishna Warrier, C., Srinivasamoorthy, K., John Peter, A., \& Anandhan, P. (2007). Study on the stable isotope signatures in groundwater of Gadilam river basin, Tamilnadu, India. Indian Journal of Geochemistry, 22(2), 209-221.

Chidambaram, S., Ramanathan, AL., Anandhan, P., Srinivasamoorthy, K., \& Prasanna, M.V. (2005) A comparative study on the coastal surface and ground water in and around Puduchattiram to Coleroon, Tamil nadu. Special issue in International journal of Ecology and environment sciences, 31(3), 209 306. 
Chidambaram, S., Ramanathan, AL., Prasanna, M.V., Anandhan, P., Srinivasamoorthy, K., \& Vasudevan, S. (2008) A statistical approach to identify the hydrogeochemically active regimes in groundwaters of Erode district, Tamilnadu. Asian Journal of Water, Environment and Pollution, 5(3), 93-102.

Darling, W.G., \& Bath, A.H. (1988). A stable isotope study of recharge processes in the English chalk. Journal of Hydrology, 101, 31-46.

Domenico, P.A., \& Schwartz, W. (1990). Physical and chemical hydrogeology. John Wiley, New york, 824p.

Freeze, A.R., \& Cherry, JA. (1979). Groundwater. Prentice - Hall, Inc Englewood cliffs, New Jersey, 604p.

Gnanasundar, D., \& Elango, L. (1999) Groundwater quality assessment of a coastal aquifer using geoelectrical techniques. Journal of Environmental Hydrology, 7(2), 1-8.

Gowrisankaran., Sengupta., \& Muthuraman. (1992). Depressurization of Neyveli aquifer. Unpublished Tech. Report, Neyveli Lignite Coporation.

Hem, JD. (1959). Geochemistry of water calculation and use of ion activity. USGS water supply, 1935 C, 17p.

Ian D, Clark., \& Peter Fritz. (1997). Environmental Isotopes in Hydrology. Lewis Publishers, New York.

Jacks, G. (1973). Chemistry of ground water in a District in Southern India. Journal of Hydrology, 18, 185 $-200$.

Lamontagne, S., Leaney, F., \& Herczeg, A. (2002). Streamwater-groundwater interactions: the river Murray at Hattah-Kulkyne park, Victoria: Summary of results. CSIRO Technical Report 27/02.

Pawar, NJ. (1985). Hydrogeochemistry of Pune metropolis with special reference to the chemistry of surface and groundwater. Unpublished Ph.D Thesis, University of Poona, 182p.

Piper, AM. (1944). A graphic procedure in the geochemical interpretation of water analysis. Transactions American Geophysical Union, 25, 914 - 923.

Prasanna, M.V. (2008). Hydrogeochemical studies in the Gadilam river basin, Tamilnadu. Unpublished Ph.D Thesis, Annamalai University, 300p.

Prasanna, M.V., Chidambaram, S., Vasu, K., Shahul Hameed, A., Unikrishna Warrier, C., Srinivasamoorthy, K., John Peter, A., \& Anandhan, P. (2007). Geochemical nature of groundwater in the Gadilam River Basin, Tamilnadu, India. Journal of Applied Geochemists, 10(1), 113-122.

Ramanathan, AL., Subramanian, V., Ramesh, R., Chidambaram, S., \& James, A. (1999). Environmental geochemistry of Pichavaram ecosystem (tropical), southeast coast of India. Environmental Geology, 37 (3), 223-233.

Raymahashay, B.C. (1986). Geochemistry of bicarbonate in river water. Journal of Geological Society of India, 27, 114-118. 
Satheesh Herbert Singh, D., \& Lawrence, J.F. (2007). Groundwater quality assessment of shallow aquifer using geopraphical information system in part of Chennai city, Tamilnadu. Journal of Geological Society of India, 69, 1067-1076.

Simpson, HJ., \& Herczeg, A. (1991). Salinity and evaporation in the river Murray river basin, Australia. Journal of Hydrology, 124, 1-27.

Srinivasamoorthy, K. (2004). Hydrogeochemistry of groundwater in Salem District, Tamilnadu, India. Unpublished Ph.D Thesis, Annamalai University.

Wigley (1973). The incongruent dissolution of dolomite. Geochim. Cosmochim. Acta, 37, 1397-1402.

Wigley, TML. (1976). Effect of mineral precipitation on isotopic composition and $C^{14}$ dating of groundwater. Nature, 263, 219-221.

\section{Figure caption}

Fig. 1 Location map of the study area.

Fig. 2 Geology and sample location map.

Fig. 3 Hill Piper Plot (Alluvium).

Fig. 4 Hill Piper Plot (Tertiary).

Fig. 5 Hill Piper Plot (Archaean).

Fig. 6 Hill Piper Plot (Cretaceous).

Fig. 7 Hill Piper Plot (Surface water).

Fig. 8 Ionic Strength for the groundwater.

Fig. 9 Variation of $\mathrm{LogPco}_{2}$ in groundwater.

Fig. 10 Thermodynamic Equilibrium diagram for silicate system in Alluvium.

Fig. 11 Thermodynamic Equilibrium diagram for silicate system in Tertiary.

Fig. 12 Thermodynamic Equilibrium diagram for silicate system in Archaean.

Fig. 13 Thermodynamic Equilibrium diagram for silicate system in Cretaceous.

Fig. 14 Thermodynamic Equilibrium diagram for silicate system in Surface water.

Fig. 15 Relationship between $\delta^{18} \mathrm{O}$ and $\delta \mathrm{D}$ in SWM.

Fig. 16 Relationship between $\delta^{18} \mathrm{O}$ and $\delta \mathrm{D}$ in POM.

Fig. $17 \delta \mathrm{D}$ Vs. Chloride in SUM.

Fig. $18 \delta \mathrm{D}$ Vs. Chloride in POM.

Fig. 19 Log $\mathrm{PCO}_{2}$ Vs. $\delta^{18} \mathrm{O}$ in SWM.

Fig. $20 \mathrm{Log} \mathrm{PcO}_{2}$ Vs. $\delta \mathrm{D}$ in POM.

Fig. 21 Saturation Index of Carbonate minerals in Alluvium using WATEQ4F.

Fig. 22 Saturation Index of Carbonate minerals in Tertiary using WATEQ4F.

Fig. 23 Saturation Index of Carbonate minerals in Archaean using WATEQ4F.

Fig. 24 Saturation Index of Calcite Vs. $\delta^{18} \mathrm{O}$ in SWM.

Fig. 25 Saturation Index of Calcite Vs. $\delta$ D in POM. 


\section{Table caption}

Tab. 1a Maximum, Minimum, Average and Standard deviation for chemical composition of groundwater (in $\mathrm{mg} / \mathrm{l}$ ) except EC and $\mathrm{pH}(\mathrm{EC}$ in $\mu \mathrm{s} / \mathrm{cm})$.

Tab. 1b Maximum, Minimum, Average and Standard deviation for chemical composition of surface water (in mg/l) except EC and $\mathrm{pH}(\mathrm{EC}$ in $\mu \mathrm{s} / \mathrm{cm}$ )

Tab. 2 Factor analysis for the chemical composition of groundwater.

Tab. 3 Stable Isotope data for Ground water and Surface water samples during south west monsoon.

Tab. 4 Stable Isotope data for Ground water and Surface water samples during post monsoon. 
Table 1a. Maximum, Minimum, Average and Standard deviation for chemical composition of groundwater (in mg/l) except $E C$ and $p H(E C$ in $\mu s / \mathrm{cm})$

\begin{tabular}{|c|c|c|c|c|c|c|c|c|c|c|c|c|c|c|c|c|c|}
\hline \multicolumn{17}{|c|}{ Alluvium } & \multirow[b]{3}{*}{ F.Avg } \\
\hline \multicolumn{5}{|c|}{ Summer } & \multicolumn{4}{|c|}{ South West Monsoon } & \multicolumn{4}{|c|}{ North East Monsoon } & \multicolumn{4}{|c|}{ Post Monsoon } & \\
\hline & Max & Min & Avg & Std & Max & Min & Avg & Std & Max & Min & Avg & Std & Max & Min & Avg & Std & \\
\hline $\mathrm{pH}$ & 7.30 & 6.60 & 6.99 & 0.21 & 8.65 & 6.40 & 7.29 & 0.65 & 7.83 & 6.01 & 7.17 & 0.61 & 9.20 & 6.83 & 8.15 & 0.91 & 7.40 \\
\hline $\mathrm{EC}$ & 6337.31 & 420.18 & 1424.31 & 1605.68 & 6278.93 & 387.00 & 1543.82 & 1538.59 & 6728.00 & 468.00 & 1829.58 & 1645.38 & 6005.00 & 345.00 & 1652.59 & 1621.56 & 1612.58 \\
\hline $\mathrm{Cl}$ & 2384.01 & 62.03 & 347.77 & 646.29 & 1994.06 & 26.59 & 357.67 & 526.91 & 2782.82 & 96.42 & 498.17 & 734.87 & 2375.15 & 51.00 & 393.60 & 639.42 & 399.30 \\
\hline $\mathrm{HCO}_{3}$ & 677.10 & 48.79 & 289.84 & 241.36 & 1293.20 & 91.50 & 397.77 & 334.67 & 634.39 & 54.30 & 270.75 & 151.37 & 1500.59 & 12.20 & 271.44 & 399.28 & 307.45 \\
\hline $\mathrm{SO}_{4}$ & 341.00 & 23.00 & 96.28 & 84.30 & 189.00 & 27.00 & 90.23 & 39.78 & 368.00 & 1.00 & 69.62 & 106.03 & 312.20 & 5.00 & 107.21 & 85.42 & 90.83 \\
\hline $\mathrm{PO}_{4}$ & 10.10 & 0.25 & 6.08 & 3.76 & 6.80 & 0.10 & 4.20 & 2.55 & 6.60 & 0.01 & 1.25 & 1.92 & 6.80 & 0.00 & 0.90 & 1.97 & 3.11 \\
\hline $\mathrm{H}_{4} \mathrm{SiO}_{4}$ & 34.00 & 8.10 & 19.02 & 9.15 & 50.00 & 1.60 & 30.06 & 14.15 & 147.50 & 8.80 & 58.60 & 36.30 & 160.00 & 27.00 & 73.92 & 40.62 & 45.40 \\
\hline $\mathrm{Ca}$ & 261.33 & 11.00 & 64.11 & 69.41 & 264.00 & 16.00 & 103.14 & 76.12 & 352.00 & 6.00 & 64.33 & 93.63 & 168.00 & 10.00 & 50.16 & 41.09 & 70.44 \\
\hline $\mathrm{Mg}$ & 1.20 & .00 & 14.47 & 25.00 & 62.39 & 0.00 & 17.09 & 17.51 & 134.40 & 1.00 & 27.51 & 35.31 & 124.80 & 4.79 & 19.50 & 33.78 & 19.64 \\
\hline $\mathrm{Na}$ & 1210.03 & 81.00 & 279.94 & 310.56 & 1400.20 & 49.30 & 267.35 & 365.38 & 1091.95 & 74.71 & 317.34 & 274.98 & 1149.43 & 52.00 & 293.71 & 307.29 & 289.59 \\
\hline $\mathrm{K}$ & 42.00 & 3.00 & 11.71 & 11.11 & 48.71 & 3.00 & 13.61 & 12.21 & 36.40 & 1.00 & 15.14 & 10.46 & 108.40 & 1.00 & 25.21 & 32.74 & 16.42 \\
\hline TDS & 4436.44 & 267.81 & 994.45 & 1122.35 & 4395.25 & 271.00 & 1080.07 & 1077.38 & 4710.00 & 328.00 & 1291.44 & 1149.91 & 4204.08 & 242.00 & 1157.33 & 1134.97 & 1130.82 \\
\hline \multicolumn{17}{|c|}{ Tertiary } & \\
\hline \multicolumn{5}{|c|}{ Summer } & \multicolumn{4}{|c|}{ South West Monsoon } & \multicolumn{4}{|c|}{ North East Monsoon } & \multicolumn{4}{|c|}{ Post Monsoon } & \\
\hline & $\operatorname{Max}$ & Min & Avg & Std & $\operatorname{Max}$ & Min & Avg & Std & $\operatorname{Max}$ & Min & Avg & Std & $\operatorname{Max}$ & Min & Avg & Std & F.Avg \\
\hline $\mathrm{pH}$ & 7.30 & 6.10 & 6.69 & 0.35 & 8.52 & 6.00 & 7.36 & 0.87 & 7.50 & 5.56 & 6.68 & 0.57 & 8.60 & 6.21 & 7.76 & 0.72 & 7.12 \\
\hline$E C$ & 867.00 & 250.00 & 492.93 & 214.50 & 1280.00 & 197.00 & 543.72 & 330.01 & 822.00 & 165.00 & 448.75 & 220.10 & 981.00 & 286.21 & 476.58 & 198.16 & 490.49 \\
\hline $\mathrm{Cl}$ & 241.05 & 26.59 & 84.19 & 64.26 & 239.29 & 8.86 & 89.69 & 73.97 & 194.97 & 8.00 & 81.67 & 52.13 & 255.23 & 44.00 & 95.32 & 61.99 & 87.71 \\
\hline $\mathrm{HCO}_{3}$ & 274.50 & 18.30 & 72.51 & 74.60 & 323.30 & 36.60 & 100.65 & 81.60 & 195.19 & 12.20 & 84.36 & 55.25 & 195.10 & 24.40 & 72.52 & 46.72 & 82.51 \\
\hline $\mathrm{SO}_{4}$ & 171.00 & 28.00 & 89.10 & 52.89 & 247.00 & 18.00 & 98.60 & 66.33 & 196.00 & 0.01 & 50.29 & 63.45 & 141.00 & 7.00 & 46.89 & 38.38 & 71.22 \\
\hline $\mathrm{PO}_{4}$ & 10.10 & 0.07 & 3.92 & 4.69 & 6.40 & 0.15 & 2.36 & 2.40 & 7.45 & 0.09 & 1.83 & 2.57 & 1.40 & 0.00 & 0.30 & 0.42 & 2.10 \\
\hline $\mathrm{H}_{4} \mathrm{SiO}_{4}$ & 69.00 & 18.10 & 31.62 & 17.51 & 54.00 & 7.30 & 27.16 & 15.29 & 72.40 & 8.00 & 39.37 & 18.93 & 120.00 & 18.00 & 68.38 & 27.02 & 41.63 \\
\hline $\mathrm{Ca}$ & 55.99 & 8.00 & 24.90 & 14.18 & 88.00 & 10.00 & 36.00 & 27.36 & 40.00 & 6.00 & 23.16 & 11.83 & 34.00 & 10.00 & 22.08 & 7.78 & 26.54 \\
\hline $\mathrm{Mg}$ & 9.00 & 0.00 & 3.40 & 3.13 & 33.60 & 1.00 & 8.48 & 10.03 & 14.40 & 0.00 & 6.51 & 4.35 & 14.40 & 1.00 & 6.40 & 4.20 & 6.20 \\
\hline $\mathrm{Na}$ & 195.40 & 45.98 & 91.53 & 51.13 & 272.00 & 1.80 & 82.49 & 83.15 & 191.00 & 6.00 & 69.36 & 61.11 & 183.91 & 22.99 & 72.30 & 45.89 & 78.92 \\
\hline $\mathrm{K}$ & 4.00 & & & & 21.90 & 1.00 & 7.01 & 6.71 & 14.60 & 1.00 & 7.68 & 3.89 & 23.90 & 1.00 & 7.41 & 5.71 & 6.68 \\
\hline TDS & 646.27 & 175.00 & 349.06 & 158.05 & 897.22 & 138.76 & 380.88 & \begin{tabular}{|l}
231.05 \\
\end{tabular} & 633.30 & 122.60 & 319.83 & 162.71 & 687.00 & 200.35 & 329.56 & 140.48 & 344.83 \\
\hline \multicolumn{17}{|c|}{ Archaean } & \\
\hline \multicolumn{5}{|c|}{ Summer } & \multicolumn{4}{|c|}{ South West Monsoon } & \multicolumn{4}{|c|}{ North East Monsoon } & \multicolumn{4}{|c|}{ Post Monsoon } & \\
\hline & Max & \begin{tabular}{|l|} 
Min \\
\end{tabular} & Avg & Std & Max & Min & Avg & Std & Max & Min & Avg & Std & Max & Min & Avg & Std & F.Avg \\
\hline $\mathrm{pH}$ & 8.10 & 6.73 & 7.14 & 0.33 & 8.00 & 6.80 & 7.14 & 0.32 & 8.60 & 6.78 & 7.46 & 0.41 & 9.20 & 8.10 & 8.52 & 0.32 & 7.56 \\
\hline EC & 2610.32 & 657.13 & 1500.32 & 580.51 & 2725.89 & 618.29 & 1498.53 & 642.83 & 2810.00 & 617.00 & 1364.24 & 591.00 & 2574.00 & 490.37 & 1129.36 & 583.25 & 1373.11 \\
\hline $\mathrm{Cl}$ & 771.03 & 59.03 & 342.01 & 225.96 & 771.03 & 53.17 & 361.46 & 248.08 & 638.10 & 35.44 & 233.55 & 152.64 & 620.37 & 35.45 & 229.38 & 168.76 & 291.60 \\
\hline $\mathrm{HCO}_{3}$ & 524.60 & 284.50 & 425.76 & 90.61 & 579.50 & 274.50 & 416.11 & 92.70 & 414.79 & 183.00 & 278.44 & 84.44 & 268.39 & 109.80 & 185.15 & 48.27 & 326.36 \\
\hline $\mathrm{SO}_{4}$ & 124.60 & 43.00 & 70.97 & 21.56 & 158.20 & 53.40 & 87.03 & 28.66 & 336.22 & 1.50 & 67.27 & 98.55 & 288.18 & 4.00 & 116.98 & 82.67 & 85.56 \\
\hline $\mathrm{PO}_{4}$ & 15.00 & 4.80 & 8.76 & 2.75 & 6.40 & 3.80 & 5.36 & 0.81 & 3.60 & 0.20 & 0.75 & 1.01 & 1.60 & 0.00 & 0.18 & 0.40 & 3.76 \\
\hline $\mathrm{H}_{4} \mathrm{SiO}_{4}$ & 63.00 & 5.80 & 27.10 & 21.81 & 53.00 & 21.20 & 39.63 & 10.19 & 94.00 & 6.60 & 50.08 & 28.69 & 120.00 & 22.00 & 72.82 & 28.03 & 47.41 \\
\hline $\mathrm{Ca}$ & 225.99 & 35.99 & 108.14 & 50.11 & 240.00 & 55.99 & 143.00 & 61.72 & 111.99 & 23.99 & 56.47 & 27.78 & 96.00 & 18.00 & 49.05 & 24.64 & 89.16 \\
\hline Mg & 40.80 & & 20.50 & 13.82 & 52.80 & 4.79 & 24.25 & 18.19 & 33.59 & 4.80 & 16.35 & 7.99 & 24.00 & 0.00 & 12.98 & 6.95 & 18.52 \\
\hline $\mathrm{Na}$ & 405.00 & 55.20 & 231.60 & & 491.00 & 50.30 & 188.58 & 122.44 & 581.20 & 69.80 & 192.60 & 129.67 & 551.72 & 54.90 & 188.04 & 128.68 & 200.21 \\
\hline $\mathrm{K}$ & 208.00 & 1.00 & 56.11 & 66.48 & 115.30 & 3.30 & 31.24 & 34.95 & 17.40 & 9.40 & 10.12 & 1.93 & 78.00 & 6.60 & 14.95 & 17.78 & 28.11 \\
\hline TDS & 1827.23 & 459.99 & 1050.22 & 406.35 & 1908.12 & 432.80 & 1048.97 & 449.98 & 1967.00 & 436.00 & 972.94 & 403.76 & 1802.47 & 343.26 & 795.56 & 409.11 & 966.92 \\
\hline
\end{tabular}


Table 1b. Maximum, Minimum, Average and Standard deviation for chemical composition of Surface water (in mg/l) except $\mathrm{EC}$ and $\mathrm{pH}(\mathrm{EC}$ in $\mu \mathrm{s} / \mathrm{cm})$

\begin{tabular}{|c|c|c|c|c|c|c|c|c|c|c|c|c|c|c|c|c|c|}
\hline \multicolumn{17}{|c|}{ Tank Water } & \multirow[b]{3}{*}{ F.Avg } \\
\hline \multicolumn{5}{|c|}{ Summer } & \multicolumn{4}{|c|}{ South West Monsoon } & \multicolumn{4}{|c|}{ North East Monsoon } & \multicolumn{4}{|c|}{ Post Monsoon } & \\
\hline & $\operatorname{Max}$ & Min & Avg & Std & $\operatorname{Max}$ & Min & Avg & Std & Max & Min & Avg & Std & Max & Min & Avg & Std & \\
\hline $\mathrm{pH}$ & 8.10 & 7.20 & 7.65 & 0.64 & 8.30 & 7.10 & 7.70 & 0.85 & 8.37 & 7.73 & 8.05 & 0.45 & 8.80 & 8.30 & 8.55 & 0.35 & 7.99 \\
\hline EC & 1706.27 & 433.70 & 1069.99 & 899.84 & 1785.56 & 439.41 & 1112.49 & 951.87 & 935.00 & 372.00 & 653.50 & 398.10 & 693.42 & 346.84 & 520.13 & 245.07 & 839.02 \\
\hline $\mathrm{Cl}$ & 541.75 & 40.31 & 291.03 & 354.57 & 531.75 & 44.31 & 288.03 & 344.67 & 212.69 & 70.90 & 141.80 & 100.26 & 106.34 & 88.62 & 97.48 & 12.53 & 204.58 \\
\hline $\mathrm{HCO}_{3}$ & 285.50 & 115.80 & 200.65 & 120.00 & 396.50 & 109.80 & 253.15 & 202.73 & 183.00 & 97.59 & 140.30 & 60.39 & 122.00 & 48.80 & 85.40 & 51.76 & 169.87 \\
\hline $\mathrm{SO}_{4}$ & 96.06 & 38.00 & 67.03 & 41.05 & 95.20 & 48.00 & 71.60 & 33.38 & 24.02 & 0.00 & 12.01 & 16.98 & 96.06 & 20.00 & 58.03 & 53.78 & 52.17 \\
\hline $\mathrm{PO}_{4}$ & 3.80 & 3.60 & 3.70 & 0.14 & 4.60 & 2.80 & 3.70 & 1.27 & 3.00 & 1.50 & 2.25 & 1.06 & 0.00 & 0.00 & 0.00 & 0.00 & 2.41 \\
\hline $\mathrm{H}_{4} \mathrm{SiO}_{4}$ & 35.30 & 20.20 & 27.75 & 10.68 & 30.30 & 22.20 & 26.25 & 5.73 & 62.00 & 12.40 & 37.20 & 35.07 & 80.00 & 16.00 & 48.00 & 45.25 & 34.80 \\
\hline $\mathrm{Ca}$ & 95.99 & 69.99 & 82.99 & 18.38 & 90.99 & 71.99 & 81.49 & 13.44 & 48.00 & 32.00 & 40.00 & 11.31 & 32.00 & 23.99 & 28.00 & 5.66 & 58.12 \\
\hline $\mathrm{Mg}$ & 10.60 & 10.59 & 10.60 & 0.01 & 9.60 & 9.59 & 9.60 & 0.01 & 4.80 & 2.28 & 3.54 & 1.78 & 9.60 & 4.79 & 7.20 & 3.40 & 7.73 \\
\hline $\mathrm{Na}$ & 320.10 & 24.60 & 172.35 & 208.95 & 321.84 & 21.60 & 171.72 & 212.30 & 172.40 & 45.98 & 109.19 & 89.39 & 118.60 & 41.38 & 79.99 & 54.60 & 133.31 \\
\hline $\mathrm{K}$ & 41.60 & 6.20 & 23.90 & 25.03 & 46.60 & 7.20 & 26.90 & 27.86 & 9.50 & 9.40 & 9.45 & 0.07 & 8.80 & 7.20 & 8.00 & 1.13 & 17.06 \\
\hline TDS & 1194.39 & 303.59 & 748.99 & 629.89 & 1249.89 & 307.59 & 778.74 & 666.31 & 655.00 & 261.00 & 458.00 & 278.60 & 485.39 & 242.79 & 364.09 & 171.55 & 587.45 \\
\hline \multicolumn{9}{|c|}{ River Water } & & & & & & & & & \\
\hline & \multicolumn{4}{|c|}{ North East Monsoon } & \multicolumn{4}{|c|}{ Post Monsoon } & & & & & & & & & \\
\hline & Max & Min & Avg & Std & Max & Min & Avg & Std & F.Avg & & & & & & & & \\
\hline pH & 8.53 & 7.54 & 8.09 & 0.37 & 8.80 & 7.90 & 8.61 & 0.32 & 8.35 & & & & & & & & \\
\hline EC & 1224.00 & 440.00 & 661.01 & 265.74 & 989.00 & 260.09 & 512.16 & 232.70 & 586.59 & & & & & & & & \\
\hline $\mathrm{Cl}$ & 354.50 & 35.44 & 119.01 & 108.65 & 153.17 & 53.17 & 81.93 & 35.29 & 100.47 & & & & & & & & \\
\hline $\mathrm{HCO}_{3}$ & 268.40 & 61.00 & 177.77 & 65.64 & 134.19 & 61.00 & 95.85 & 24.83 & 136.81 & & & & & & & & \\
\hline $\mathrm{SO}_{4}$ & 26.42 & 0.00 & 11.59 & 10.76 & 288.18 & 14.00 & 74.75 & 98.36 & 43.17 & & & & & & & & \\
\hline $\mathrm{PO}_{4}$ & 1.60 & 0.60 & 1.00 & 0.42 & 3.20 & 0.00 & 0.76 & 1.28 & 0.88 & & & & & & & & \\
\hline $\mathrm{H}_{4} \mathrm{SiO}_{4}$ & 80.00 & 8.80 & 39.69 & 23.15 & 87.00 & 20.00 & 44.86 & 25.13 & 42.27 & & & & & & & & \\
\hline $\mathrm{Ca}$ & 40.00 & 24.00 & 34.28 & 6.05 & 48.00 & 16.00 & 30.85 & 10.76 & 32.57 & & & & & & & & \\
\hline Mg & 19.20 & 0.00 & 11.44 & 6.81 & 33.59 & 0.00 & 10.28 & 11.57 & 10.86 & & & & & & & & \\
\hline $\mathrm{Na}$ & 240.70 & 35.20 & 91.37 & 70.68 & 183.91 & 10.80 & 68.76 & 58.35 & 80.06 & & & & & & & & \\
\hline $\mathrm{K}$ & 10.50 & 9.40 & 9.63 & 0.43 & 32.40 & 6.60 & 10.83 & 9.52 & 10.23 & & & & & & & & \\
\hline TDS & 857.00 & 308.00 & 464.18 & 185.05 & 800.79 & 182.06 & 374.01 & 200.71 & 419.10 & & & & & & & & \\
\hline
\end{tabular}


Table 2. Factor analysis for the chemical composition of groundwater.

\begin{tabular}{|c|c|c|c|}
\hline \multicolumn{4}{|c|}{ Varimax Rotated (n=36) (SUM) } \\
\hline & $\begin{array}{l}\text { Factor } \\
1\end{array}$ & $\begin{array}{l}\text { Factor } \\
2\end{array}$ & $\begin{array}{l}\text { Factor } \\
3\end{array}$ \\
\hline $\mathrm{Cl}$ & 0.96 & -0.05 & 0.01 \\
\hline $\mathrm{HCO}_{3}$ & 0.66 & 0.40 & 0.34 \\
\hline $\mathrm{SO}_{4}$ & -0.06 & -0.06 & -0.87 \\
\hline $\mathrm{PO}_{4}$ & 0.00 & 0.85 & 0.32 \\
\hline $\mathrm{H}_{4} \mathrm{SiO}_{4}$ & 0.04 & -0.84 & 0.33 \\
\hline $\mathrm{Ca}$ & 0.82 & 0.04 & 0.41 \\
\hline Mg & 0.91 & 0.14 & 0.10 \\
\hline $\mathrm{Na}$ & 0.94 & 0.05 & -0.19 \\
\hline K & 0.36 & 0.49 & 0.15 \\
\hline Eigen Values & 3.88 & 1.86 & 1.33 \\
\hline Variance (\%) & 43.14 & 20.69 & 14.79 \\
\hline Cumulative (\%) & 43.14 & 63.84 & 78.63 \\
\hline
\end{tabular}

\begin{tabular}{|c|c|c|c|}
\hline \multicolumn{4}{|c|}{ Varimax Rotated $(n=36)(S W M)$} \\
\hline & $\begin{array}{l}\text { Factor } \\
1\end{array}$ & $\begin{array}{l}\text { Factor } \\
2\end{array}$ & $\begin{array}{l}\text { Factor } \\
3\end{array}$ \\
\hline $\mathrm{Cl}$ & 0.96 & 0.13 & 0.12 \\
\hline $\mathrm{HCO}_{3}$ & 0.80 & 0.47 & -0.13 \\
\hline $\mathrm{SO}_{4}$ & -0.02 & -0.10 & 0.65 \\
\hline $\mathrm{PO}_{4}$ & 0.26 & 0.87 & 0.09 \\
\hline $\mathrm{H}_{4} \mathrm{SiO}_{4}$ & -0.22 & 0.80 & 0.31 \\
\hline $\mathrm{Ca}$ & 0.60 & 0.68 & -0.12 \\
\hline Mg & 0.20 & 0.63 & -0.35 \\
\hline $\mathrm{Na}$ & 0.95 & -0.06 & 0.18 \\
\hline $\mathbf{K}$ & 0.26 & 0.25 & 0.74 \\
\hline Eigen Values & 3.06 & 2.58 & 1.28 \\
\hline Variance (\%) & 33.99 & 28.64 & 14.27 \\
\hline Cumulative (\%) & 33.99 & 62.63 & 76.90 \\
\hline
\end{tabular}

\begin{tabular}{|c|c|c|c|}
\hline \multicolumn{4}{|c|}{ Varimax Rotated $(n=42)$ (NEM) } \\
\hline & $\begin{array}{l}\text { Factor } \\
1\end{array}$ & $\begin{array}{l}\text { Factor } \\
2\end{array}$ & $\begin{array}{l}\text { Factor } \\
3\end{array}$ \\
\hline $\mathrm{Cl}$ & 0.98 & 0.10 & -0.02 \\
\hline $\mathrm{HCO}_{3}$ & 0.29 & 0.77 & -0.12 \\
\hline $\mathrm{SO}_{4}$ & -0.19 & 0.68 & -0.09 \\
\hline $\mathrm{PO}_{4}$ & -0.14 & -0.16 & 0.73 \\
\hline $\mathrm{H}_{4} \mathrm{SiO}_{4}$ & 0.08 & 0.02 & 0.81 \\
\hline $\mathrm{Ca}$ & 0.95 & 0.00 & 0.02 \\
\hline $\mathrm{Mg}$ & 0.93 & 0.12 & -0.07 \\
\hline $\mathrm{Na}$ & 0.80 & 0.51 & -0.06 \\
\hline $\mathbf{K}$ & 0.29 & 0.69 & 0.03 \\
\hline Eigen Values & 3.60 & 1.84 & 1.22 \\
\hline Variance (\%) & 39.94 & 20.46 & 13.56 \\
\hline Cumulative (\%) & 39.94 & 60.40 & 73.96 \\
\hline
\end{tabular}

\begin{tabular}{|c|c|c|c|}
\hline \multicolumn{4}{|c|}{ Varimax Rotated $(n=42)(P O M)$} \\
\hline & $\begin{array}{l}\text { Factor } \\
1\end{array}$ & $\begin{array}{l}\text { Factor } \\
2\end{array}$ & $\begin{array}{l}\text { Factor } \\
3\end{array}$ \\
\hline $\mathrm{Cl}$ & 0.99 & 0.02 & -0.07 \\
\hline $\mathrm{HCO}_{3}$ & 0.28 & 0.26 & 0.80 \\
\hline $\mathrm{SO}_{4}$ & 0.08 & 0.75 & 0.04 \\
\hline $\mathrm{PO}_{4}$ & -0.06 & 0.67 & -0.24 \\
\hline $\mathrm{H}_{4} \mathrm{SiO}_{4}$ & -0.16 & -0.25 & 0.83 \\
\hline $\mathrm{Ca}$ & 0.88 & 0.06 & 0.11 \\
\hline $\mathrm{Mg}$ & 0.92 & -0.04 & -0.08 \\
\hline $\mathrm{Na}$ & 0.92 & 0.24 & 0.22 \\
\hline $\mathrm{K}$ & 0.13 & 0.82 & 0.16 \\
\hline Eigen Values & 3.57 & 1.88 & 1.48 \\
\hline Variance (\%) & 39.69 & 20.84 & 16.47 \\
\hline Cumulative (\%) & 39.69 & 60.53 & 77.00 \\
\hline
\end{tabular}


Table 3. Stable Isotope data for Ground water and Surface water samples during South west monsoon.

\begin{tabular}{|c|c|c|c|c|c|}
\hline S.No & Sample.No & Lithology & Location & סOxygen 18 & סDeutrium \\
\hline 1 & 1 & \multirow{6}{*}{$\stackrel{\frac{E}{J}}{\stackrel{\sum}{ٍ}}$} & Thiruvanthipuram & -7.11 & -49.93 \\
\hline 2 & 2 & & Arungunam & -7.19 & -50.49 \\
\hline 3 & 3 & & Muthukrishnapuram & -7.04 & -49.37 \\
\hline 4 & 4 & & Panruti & -6.9 & -48.25 \\
\hline 5 & 5 & & Semakkottai & -6.74 & -47.33 \\
\hline 6 & 8 & & Karaikadu & -6.17 & -44.63 \\
\hline 7 & 13 & \multirow{5}{*}{ 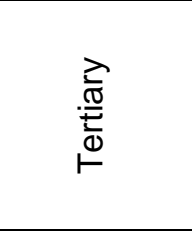 } & Nadukuppam & -7.75 & -52.45 \\
\hline 8 & 15 & & Kadanpuliyur & -7.15 & -51.26 \\
\hline 9 & 19 & & Vengadampetti & -7.95 & -52.85 \\
\hline 10 & 20 & & Puthukuppam & -7.55 & -52.05 \\
\hline 11 & 23 & & K.Kallakurichi & -6.25 & -45.93 \\
\hline 12 & 29 & \multirow{6}{*}{ 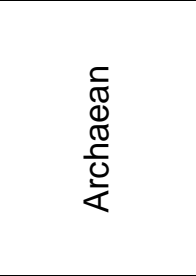 } & K.Palayam & -5.7 & -42.35 \\
\hline 13 & 30 & & Rishivandiyam & -5.32 & -42.83 \\
\hline 14 & 38 & & Maiyanur & -4.95 & -43.32 \\
\hline 15 & 39 & & S.Malayanur & -4.12 & -40.02 \\
\hline 16 & 40 & & Pasar & -5.13 & -43.07 \\
\hline 17 & 43 & & Elavarasankottai & -4.57 & -38.39 \\
\hline 18 & T1 & \multirow{2}{*}{$\begin{array}{c}\text { Surface } \\
\text { water }\end{array}$} & Veeraperumanallur & -0.03 & -20.24 \\
\hline 19 & T2 & & Kalamaruthur & 0.64 & -14.13 \\
\hline
\end{tabular}


Table 4. Stable Isotope data for Ground water and Surface water samples during post monsoon.

\begin{tabular}{|c|c|c|c|c|c|}
\hline S.No & Sample.No & Lithology & Location & סOxygen 18 & סDeutrium \\
\hline 1 & 1 & \multirow{9}{*}{ 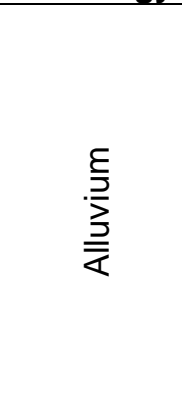 } & Thiruvandhipuram & -4.28 & -42.98 \\
\hline 2 & 2 & & Arungunam & -3.61 & -39.3 \\
\hline 3 & 3 & & Muthukrishnapuram & -3.85 & -41.43 \\
\hline 4 & 4 & & Panruti & -2.75 & -35.8 \\
\hline 5 & 5 & & Semmakottai & -3.31 & -38.86 \\
\hline 6 & 8 & & Karaikadu & -2.32 & -33.21 \\
\hline 7 & 9 & & Cuddalore & -6.32 & -42.97 \\
\hline 8 & 10 & & Veeraperumanalur & -4.39 & -41.85 \\
\hline 9 & 11 & & Arasur & -2.76 & -26.85 \\
\hline 10 & 13 & \multirow{6}{*}{ 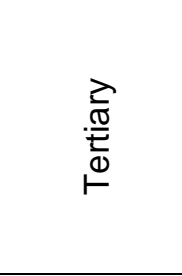 } & Nadukuppam & -4.89 & -39.64 \\
\hline 11 & 14 & & Naduveerapattu & -5.53 & -38.02 \\
\hline 12 & 15 & & Kadanpuliyur & -5.02 & -40.09 \\
\hline 13 & 17 & & Ramapuram & -4.13 & -43.72 \\
\hline 14 & 23 & & K.Kallakurichi & -3.05 & -35.51 \\
\hline 15 & 24 & & V.Melur & -3.2 & -39.87 \\
\hline 16 & 25 & \multirow{18}{*}{ 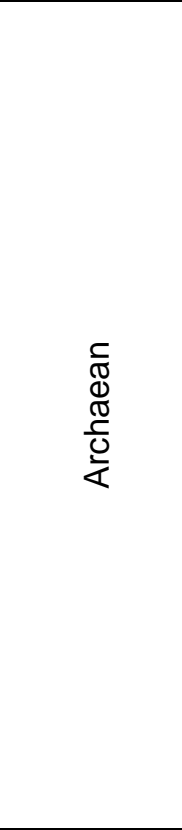 } & Gadilam & -1.88 & -31.8 \\
\hline 17 & 26 & & Padur & -1.95 & -36.35 \\
\hline 18 & 27 & & Ulundurpettai & -2.37 & -33.9 \\
\hline 19 & 28 & & Ariyur & -3.73 & -25.66 \\
\hline 20 & 29 & & K.Palayam & -9.23 & -34.19 \\
\hline 21 & 30 & & Rishivandiyam & -0.07 & -24.62 \\
\hline 22 & 31 & & Sembimadevi & -3.53 & -40.95 \\
\hline 23 & 32 & & Kumaramangalam & -2.92 & -38.47 \\
\hline 24 & 33 & & Pandur & -2.46 & -38.68 \\
\hline 25 & 34 & & Koratur & -4.05 & -33.03 \\
\hline 26 & 35 & & T.Kunnatur & -2.77 & -23.94 \\
\hline 27 & 36 & & Villivalam & -3.42 & -31.01 \\
\hline 28 & 37 & & Panapadi & -3.54 & -32.28 \\
\hline 29 & 38 & & Maiyanur & -2.68 & -31.54 \\
\hline 30 & 39 & & S.Malayanur & -1.74 & -34.91 \\
\hline 31 & 40 & & Pasar & -1.78 & -32.22 \\
\hline 32 & 41 & & Sikkampattu & -1.33 & -32.31 \\
\hline 33 & 43 & & Ela.kottai & -3.6 & -26.18 \\
\hline 34 & S1 & \multirow{8}{*}{ 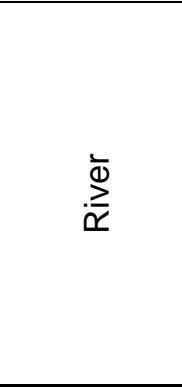 } & Gadilam Mouth.Rvr & -3.6 & -42.83 \\
\hline 35 & $\mathrm{~S} 2$ & & Thiruvandipuram.Rvr & -6.01 & -41.85 \\
\hline 36 & S3 & & Muthu-Panruti.Rvr & -5.05 & -48.53 \\
\hline 37 & S4 & & Ulundur-Gadi.Rvr & -6.58 & -42.42 \\
\hline 38 & S5 & & Maiyanur.Rvr & -4.62 & -45.04 \\
\hline 39 & S6 & & Sikkampattu.Rvr & -5.02 & -31.78 \\
\hline 40 & S7 & & Mohalur.Rvr & -5.27 & -44.73 \\
\hline 41 & S8 & & Uppanar.Rvr & -1.98 & -29.6 \\
\hline
\end{tabular}




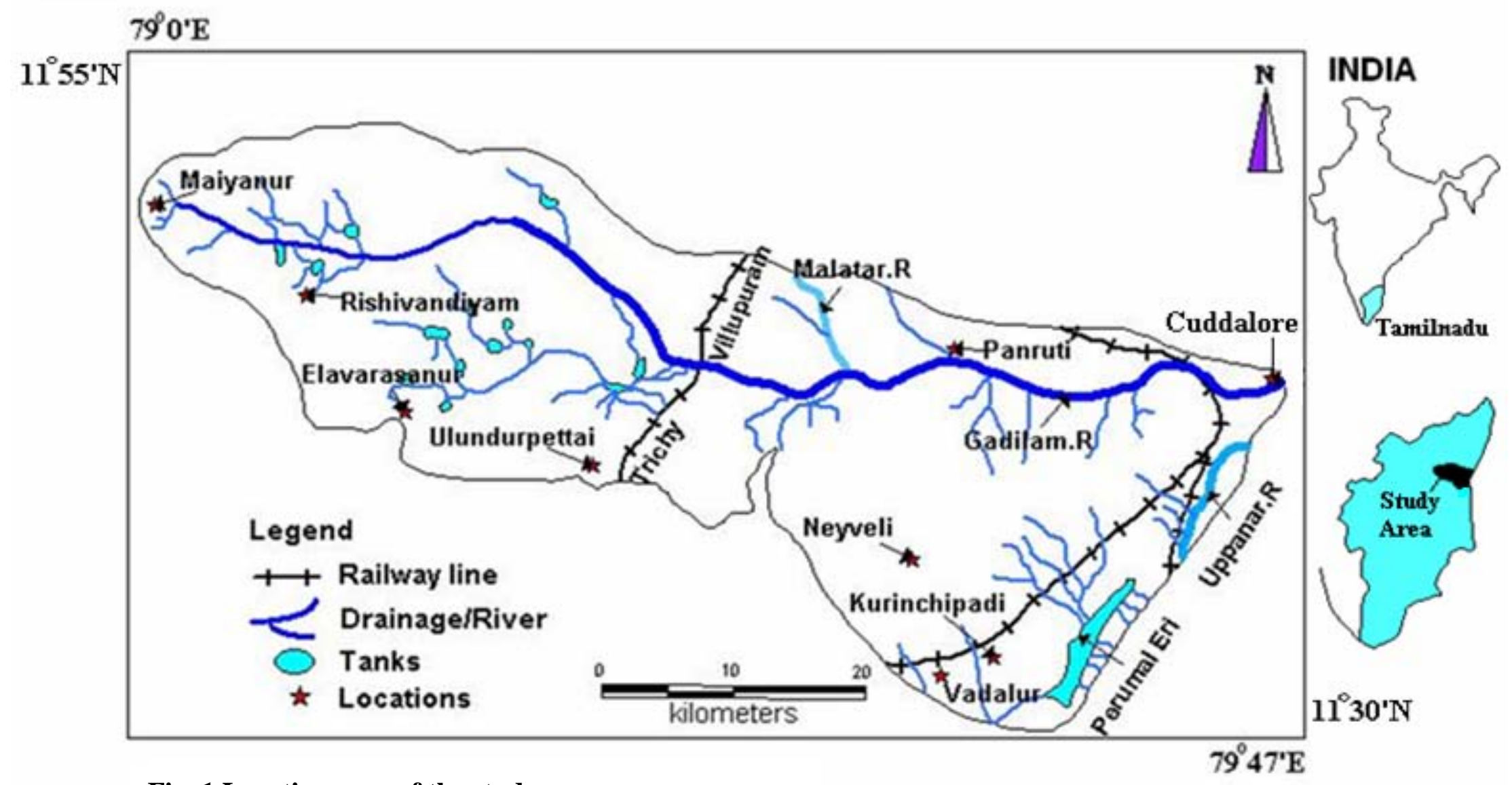

Fig. 1 Location map of the study area 


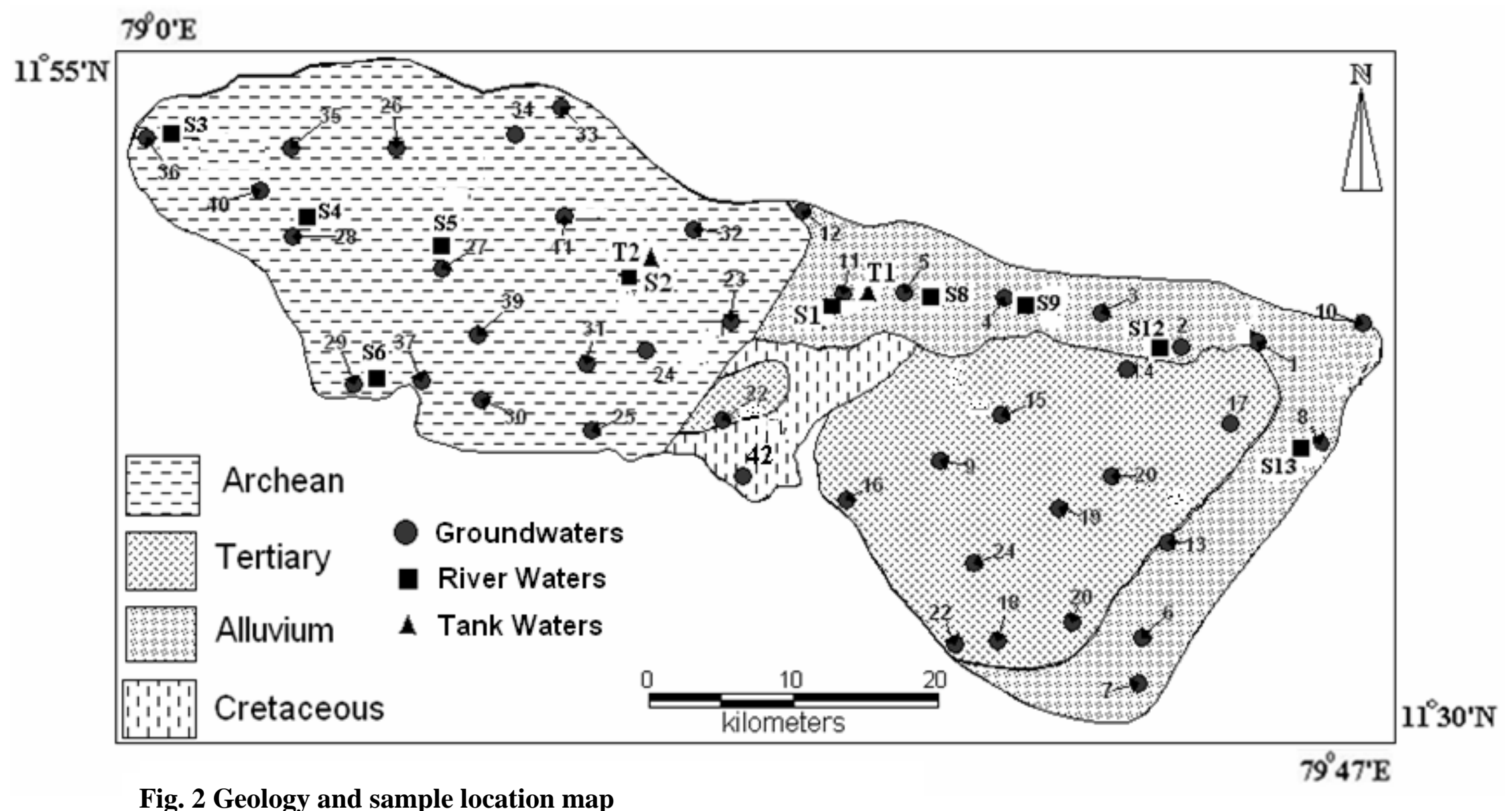




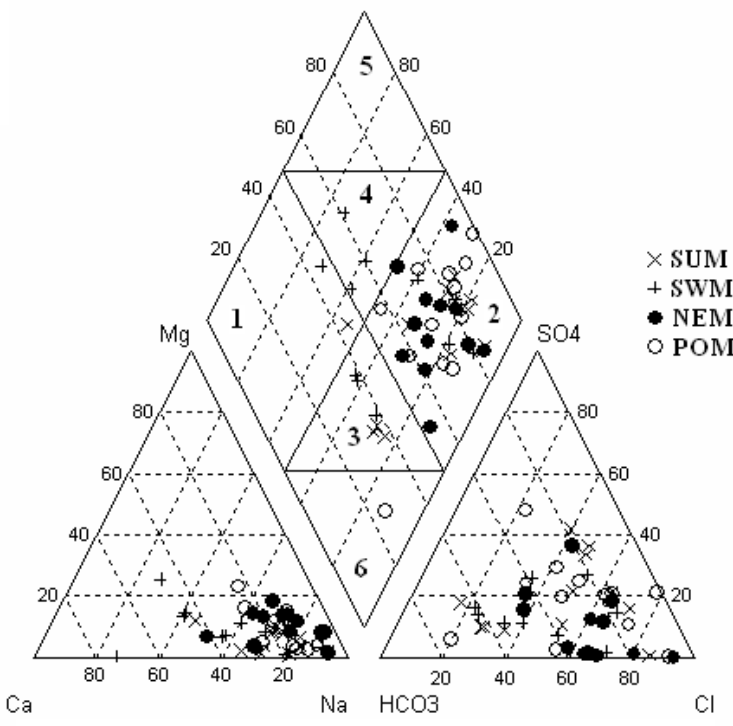

Fig. 3 Hill Piper Plot (Alluvium)

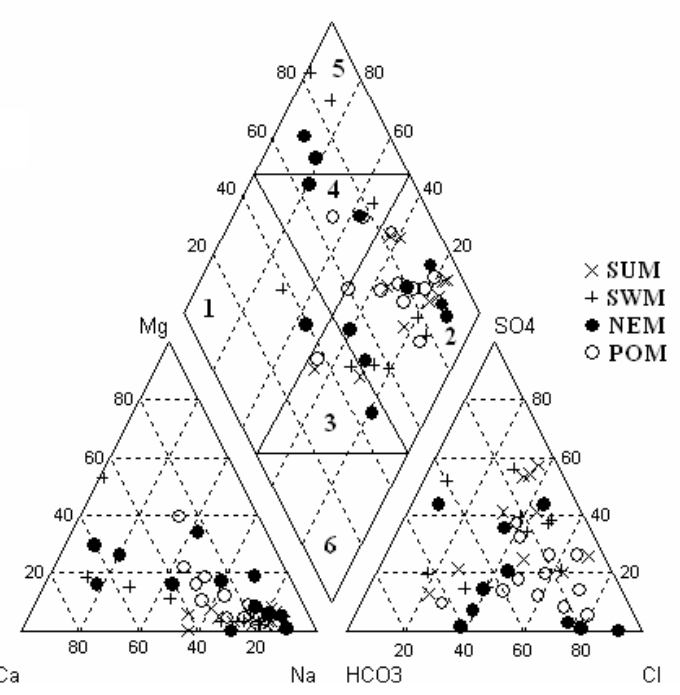

Fig. 4 Hill Piper Plot (Tertiary)

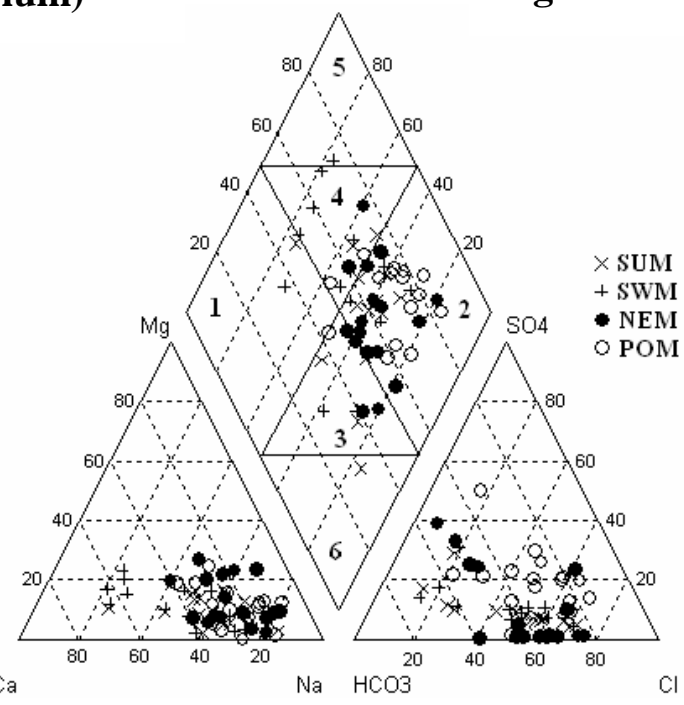

Fig. 5 Hill Piper Plot (Archaean) 


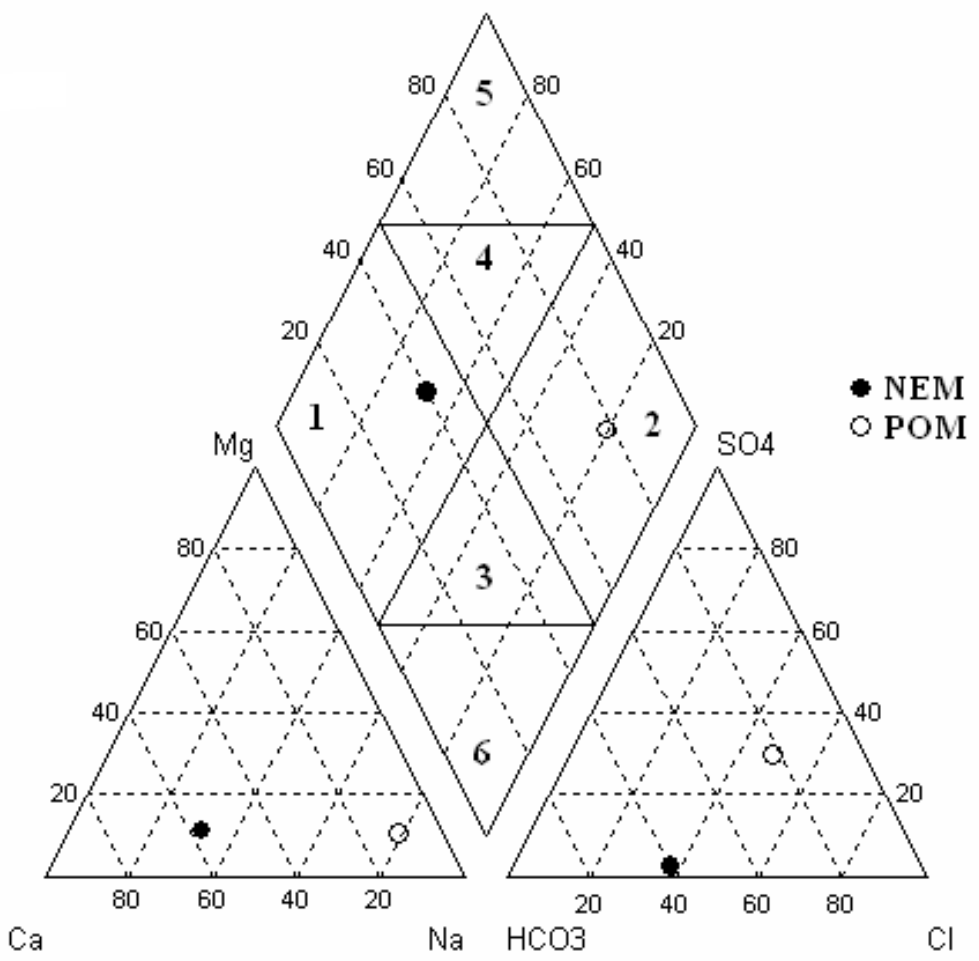

Fig. 6 Hill Piper Plot (Cretaceous)

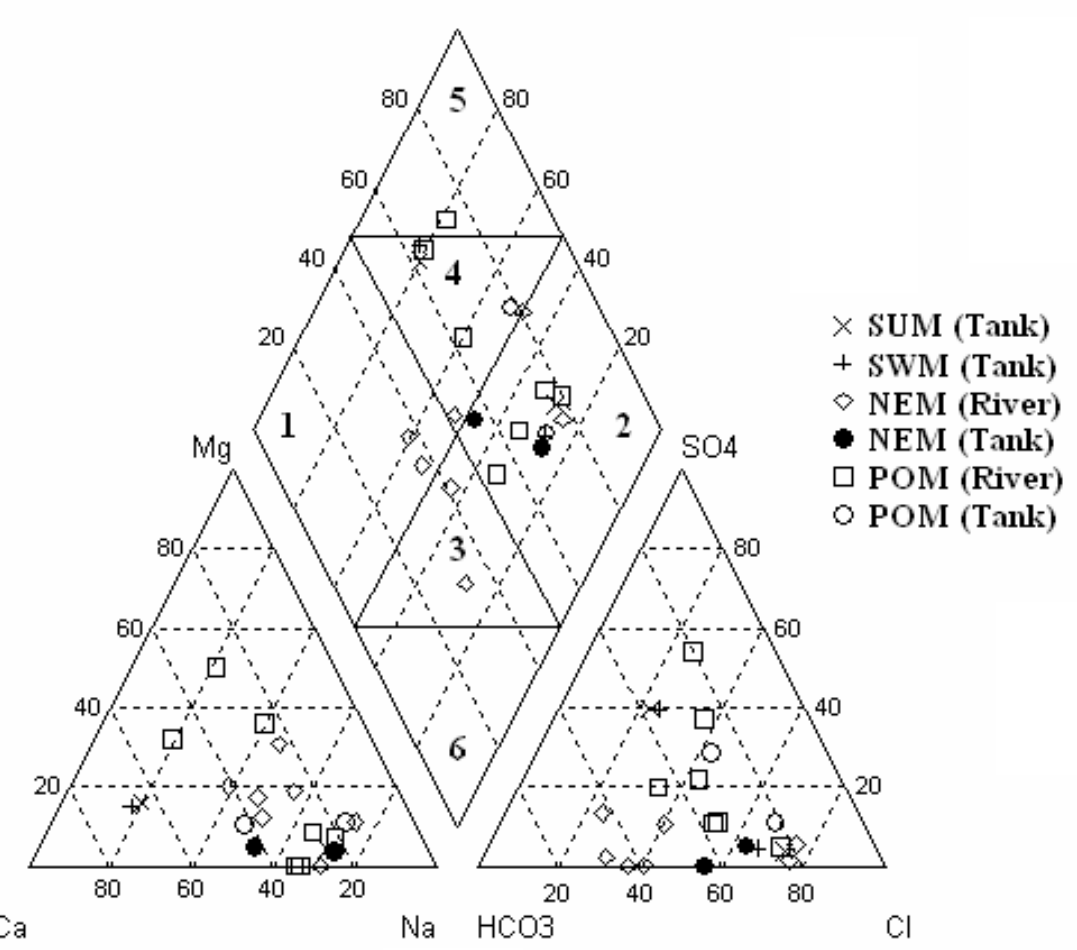

Fig. 7 Hill Piper Plot (surface water) 

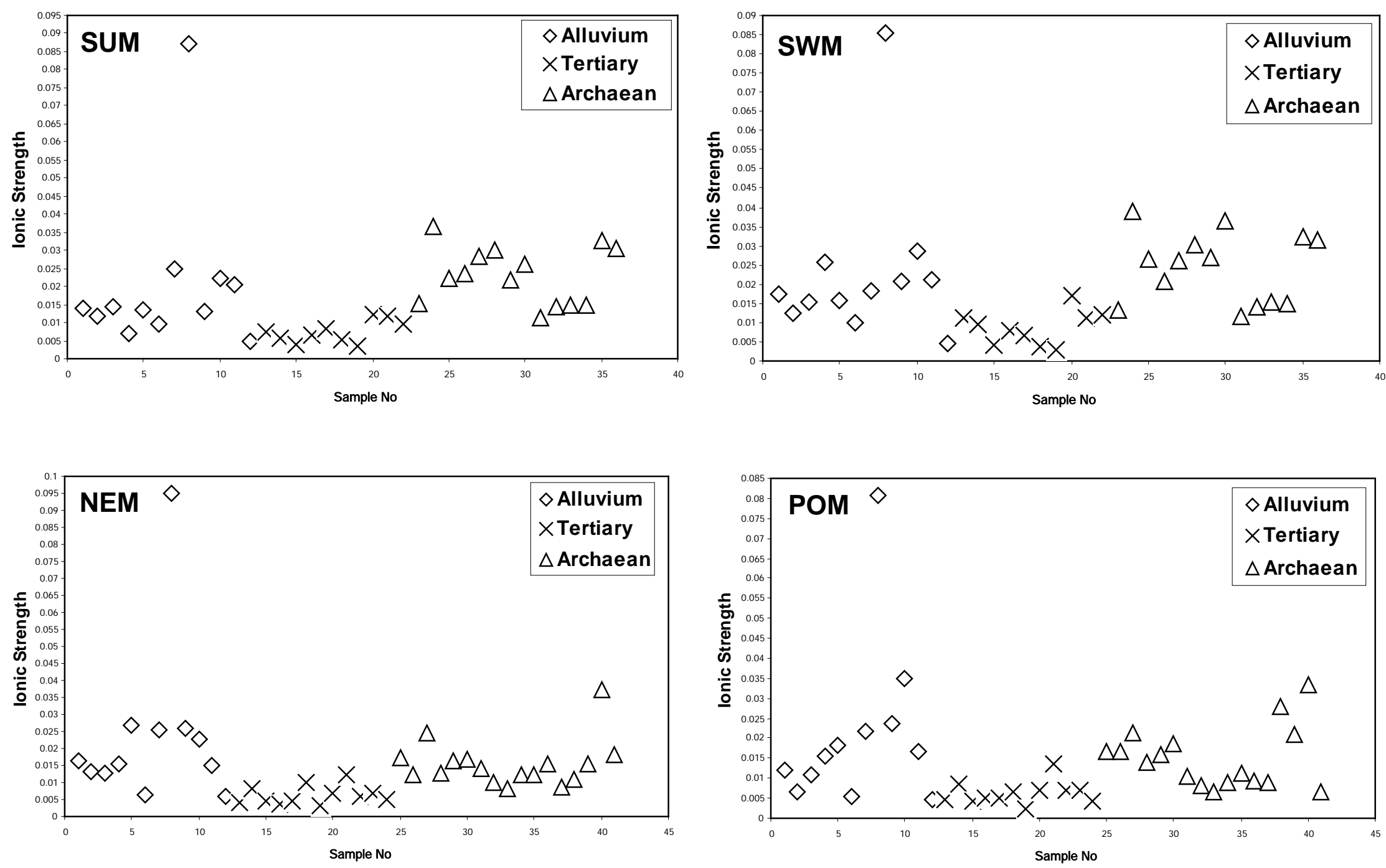

Fig. 8 Ionic Strength for the groundwater. 

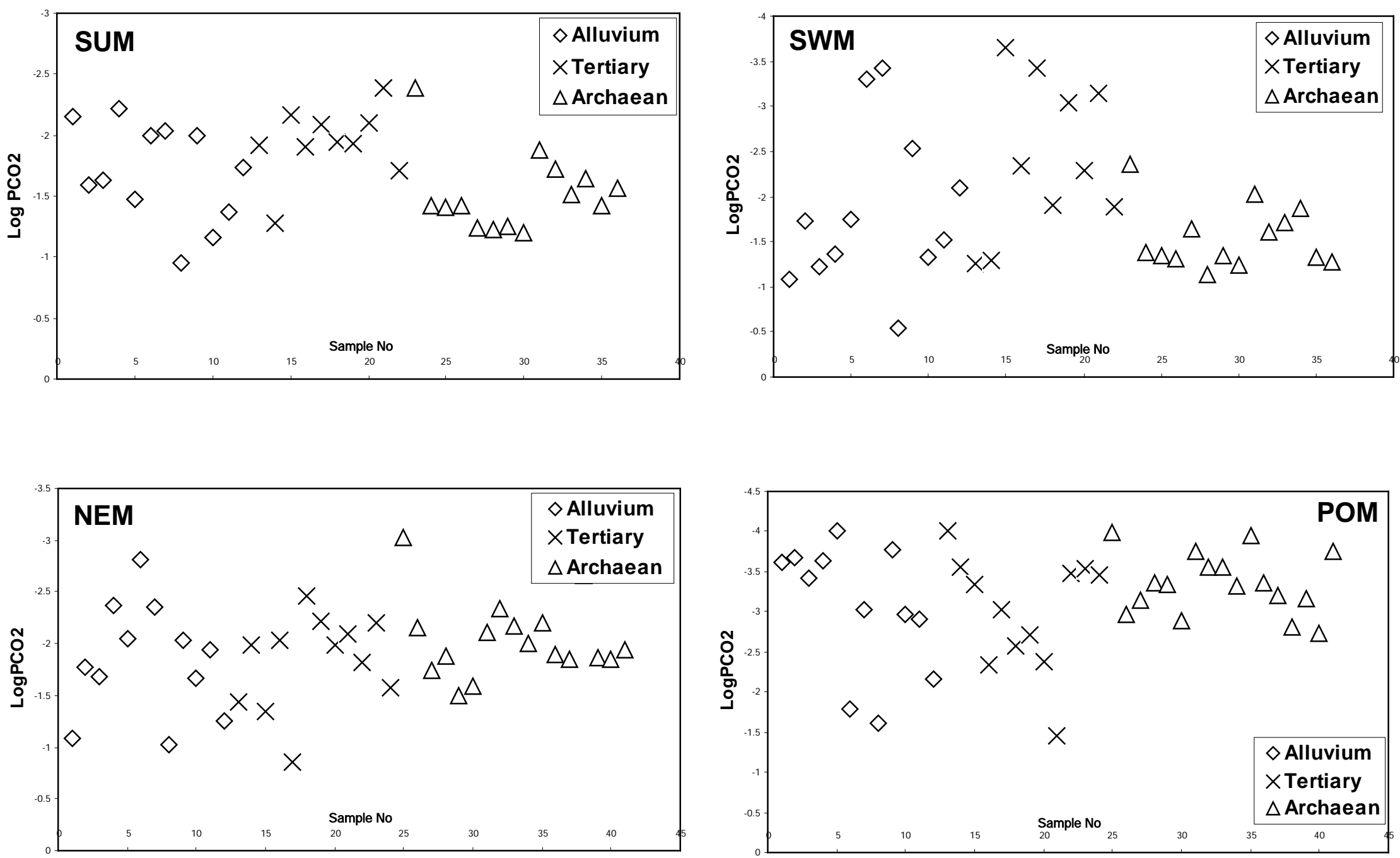

Fig. 9 Variation of $\mathrm{LogPco}_{2}$ in groundwater. 

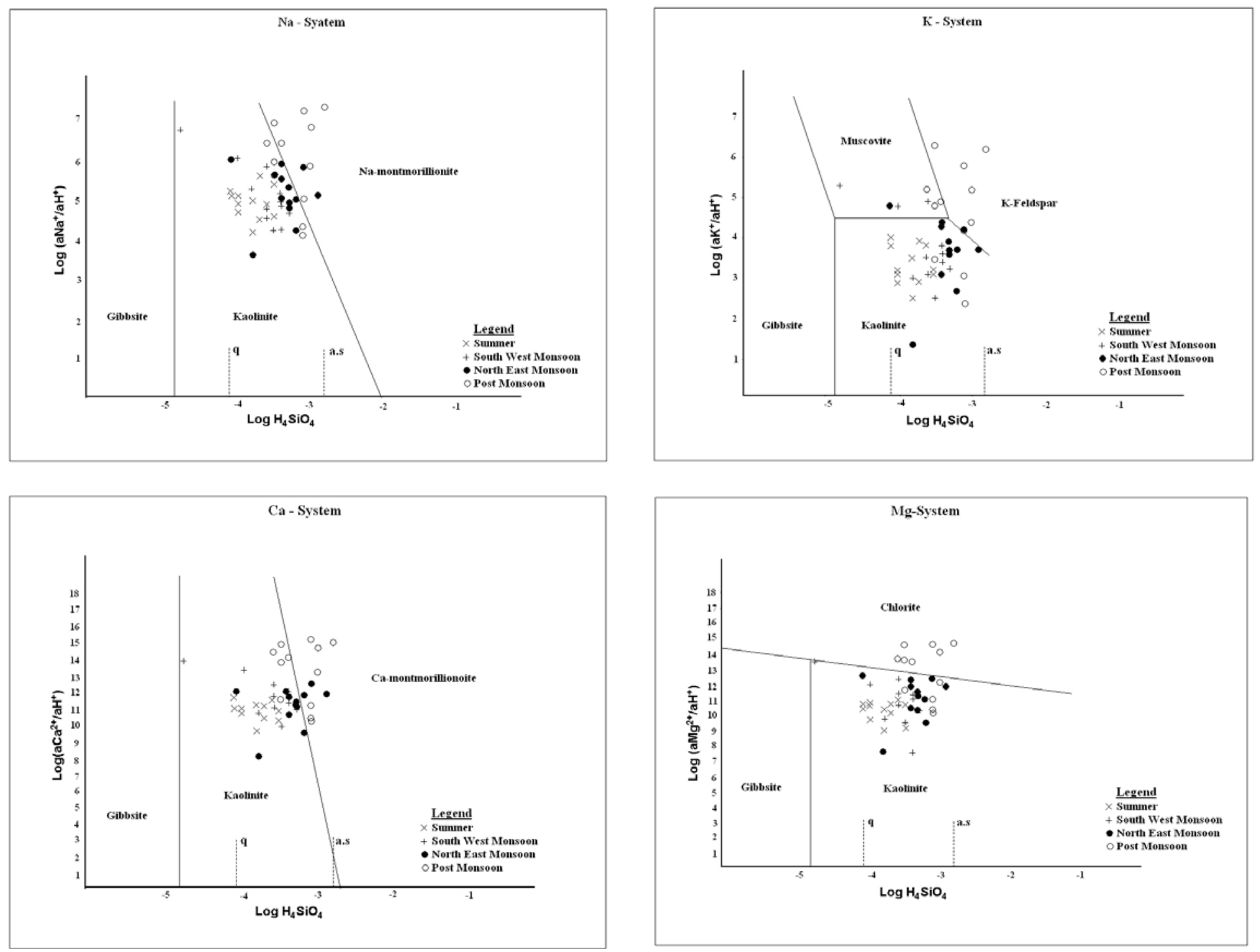

Fig. 10 Thermodynamic Equilibrium diagram for silicate system in Alluvium

32 

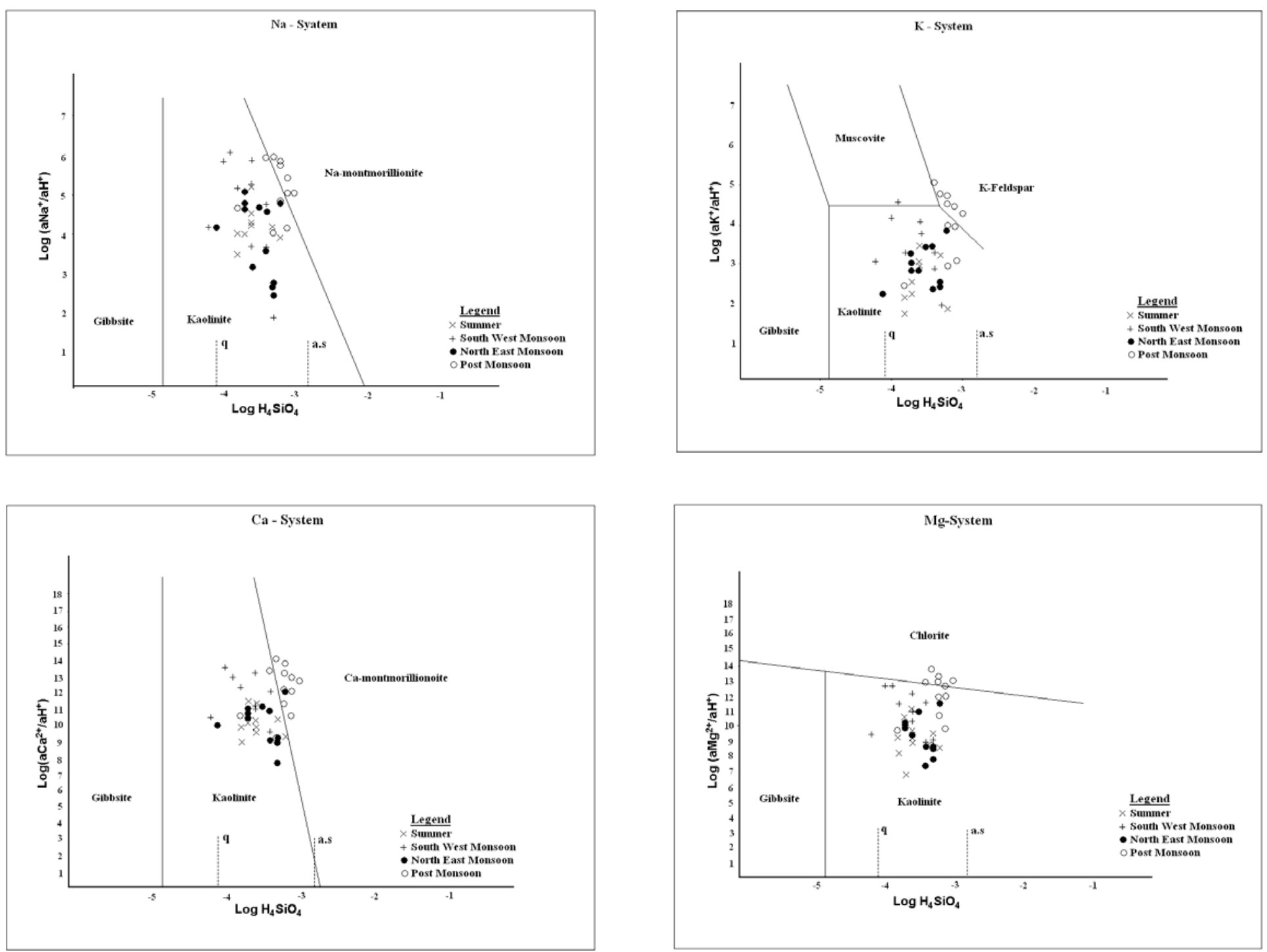

Fig. 11 Thermodynamic Equilibrium diagram for silicate system in Tertiary 

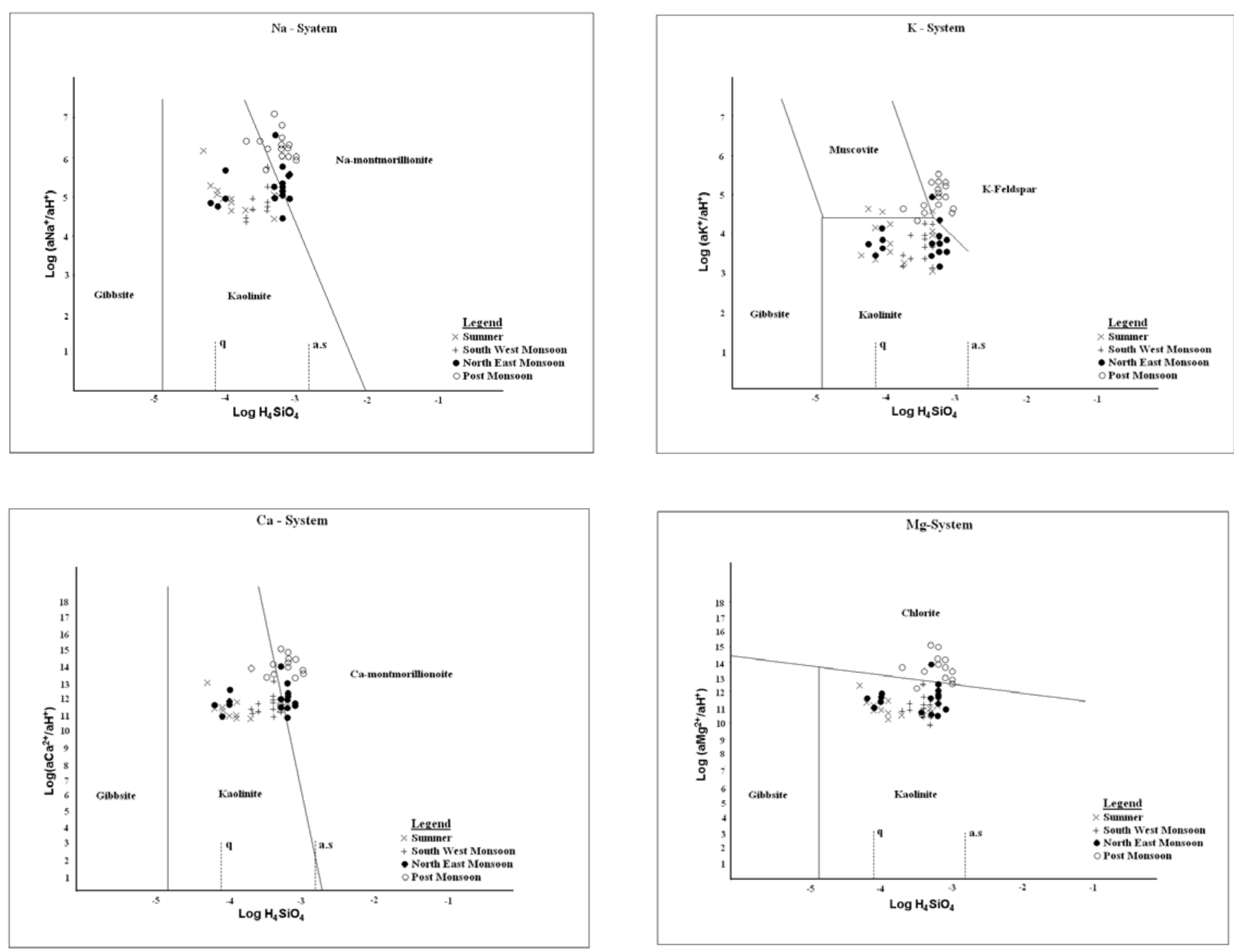

Fig. 12 Thermodynamic Equilibrium diagram for silicate system in Archaean 

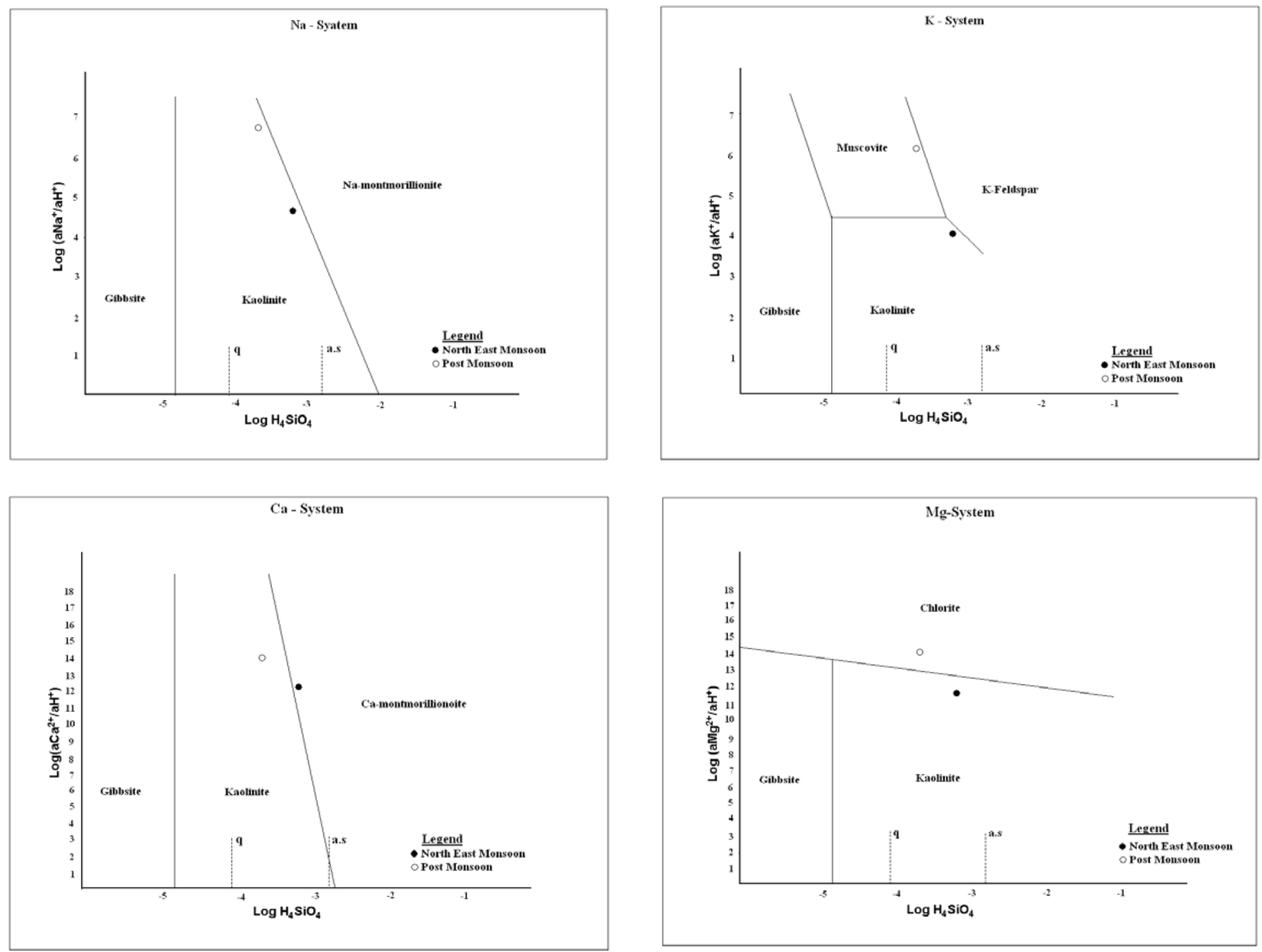

Fig. 13 Thermodynamic Equilibrium diagram for silicate system in Cretaceous 

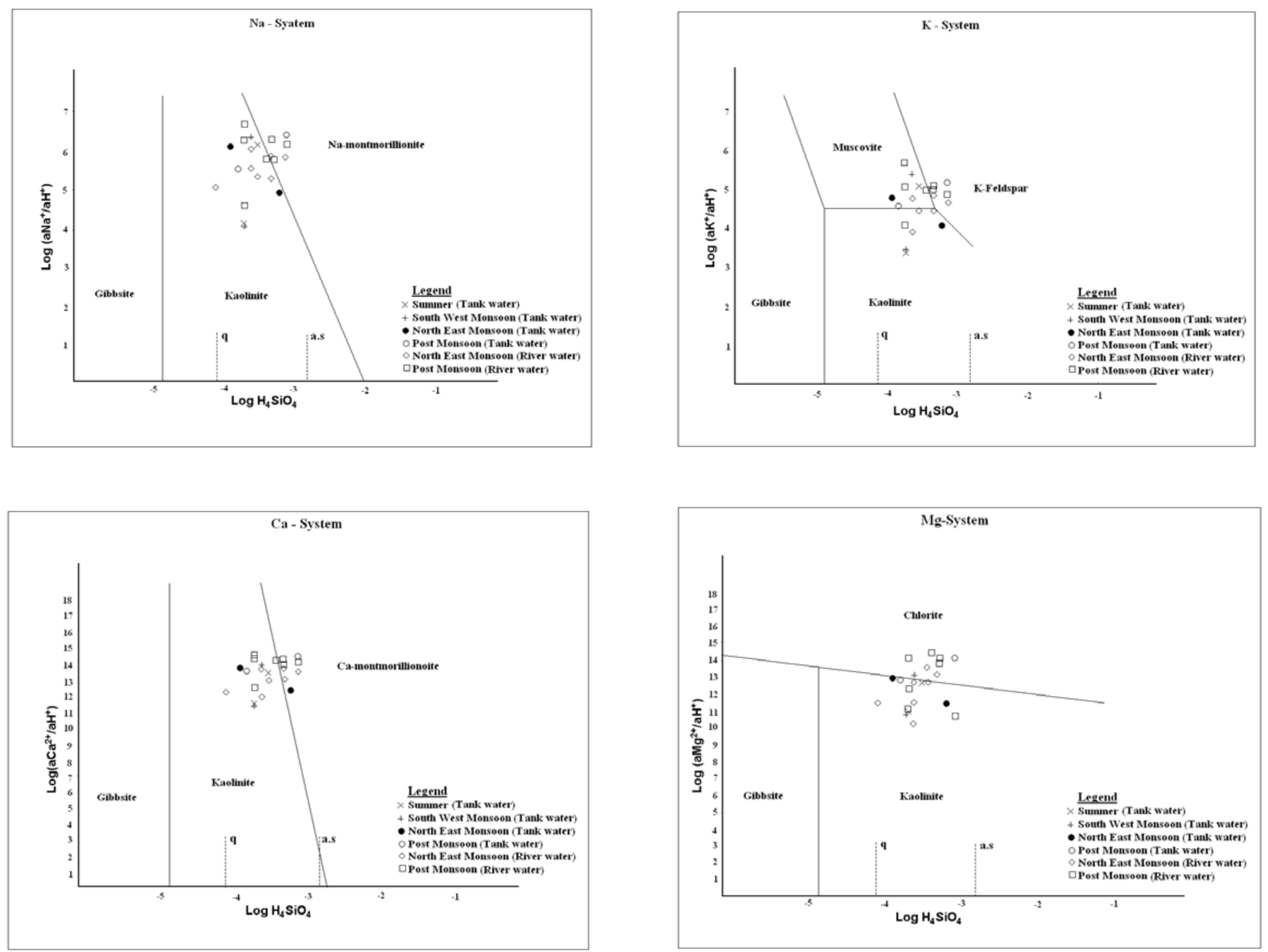

Fig. 14. Thermodynamic Equilibrium diagram for silicate system in Surface water 


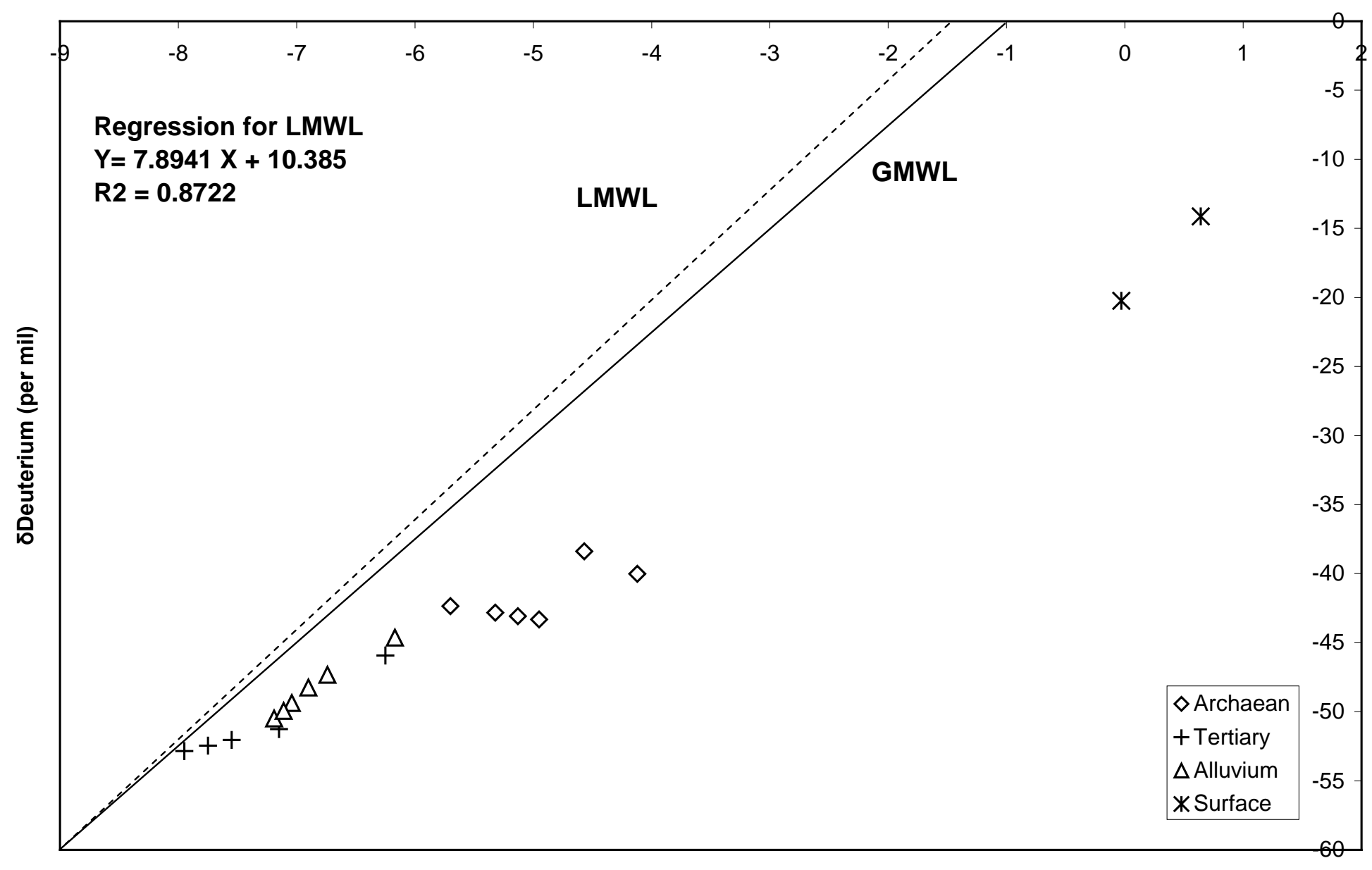

סOxygen18 (per mil)

Fig. 15. Relationship between $\delta^{18} O$ and $\delta D$ in SWM. 


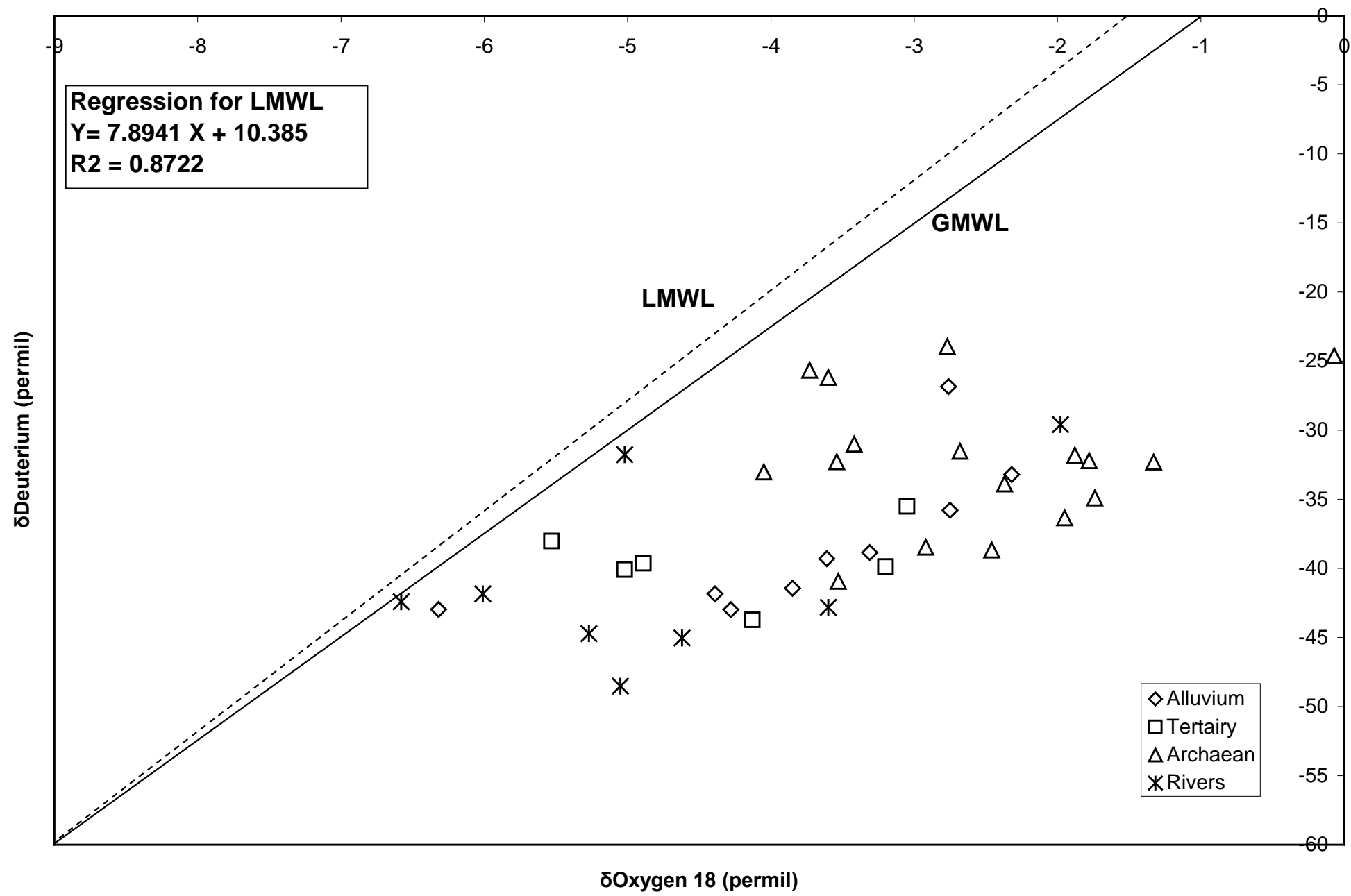

Fig. 16 Relationship between $\delta^{18} O$ and $\delta D$ in POM. 


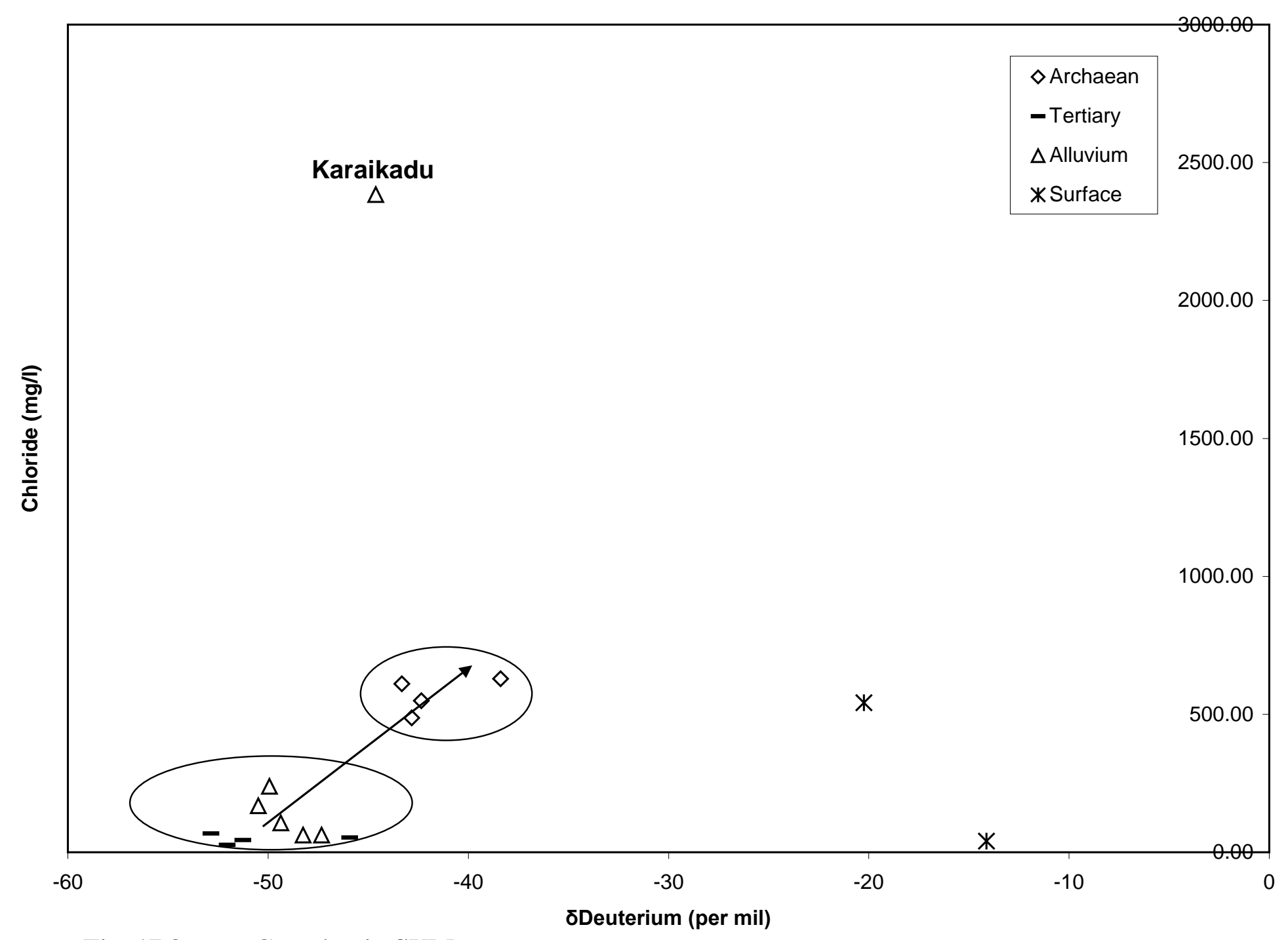

Fig. 17 $\delta D$ Vs. Chloride in SUM. 


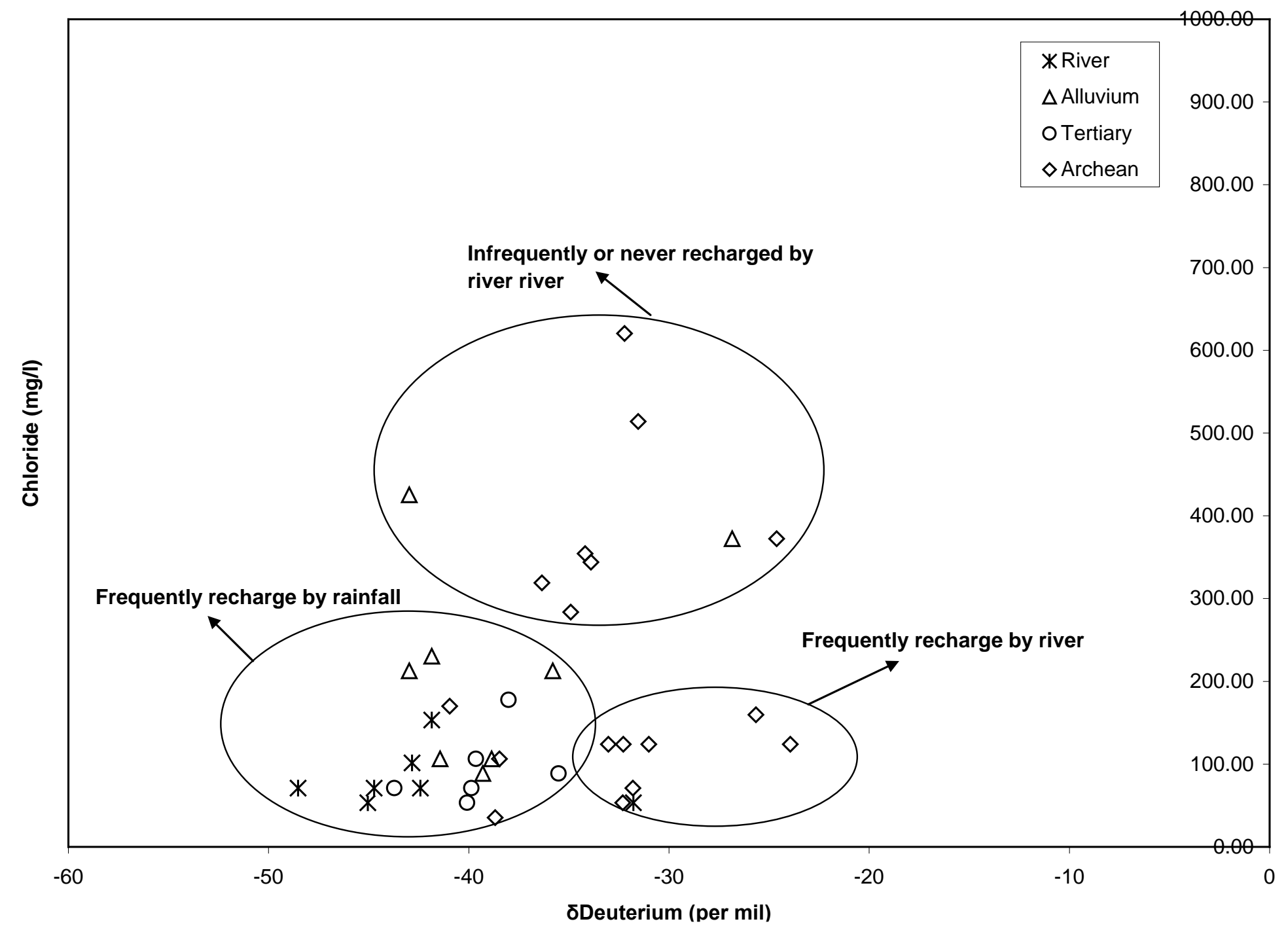

Fig. 18. $\delta D$ Vs. Chloride in POM. 


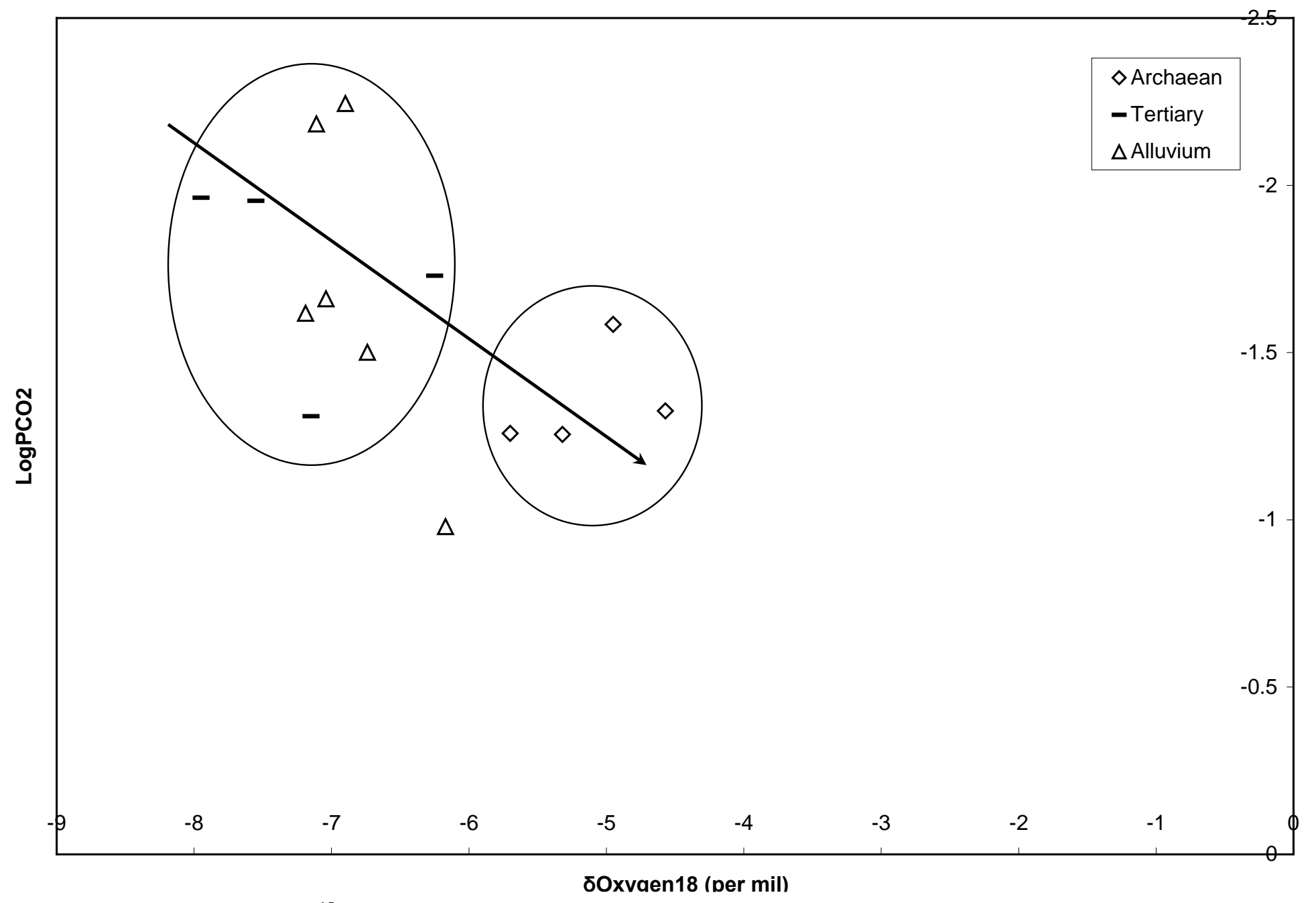

Fig. 19 Log Pco 2 Vs. $\delta^{18} \mathrm{O}$ in SWM. 


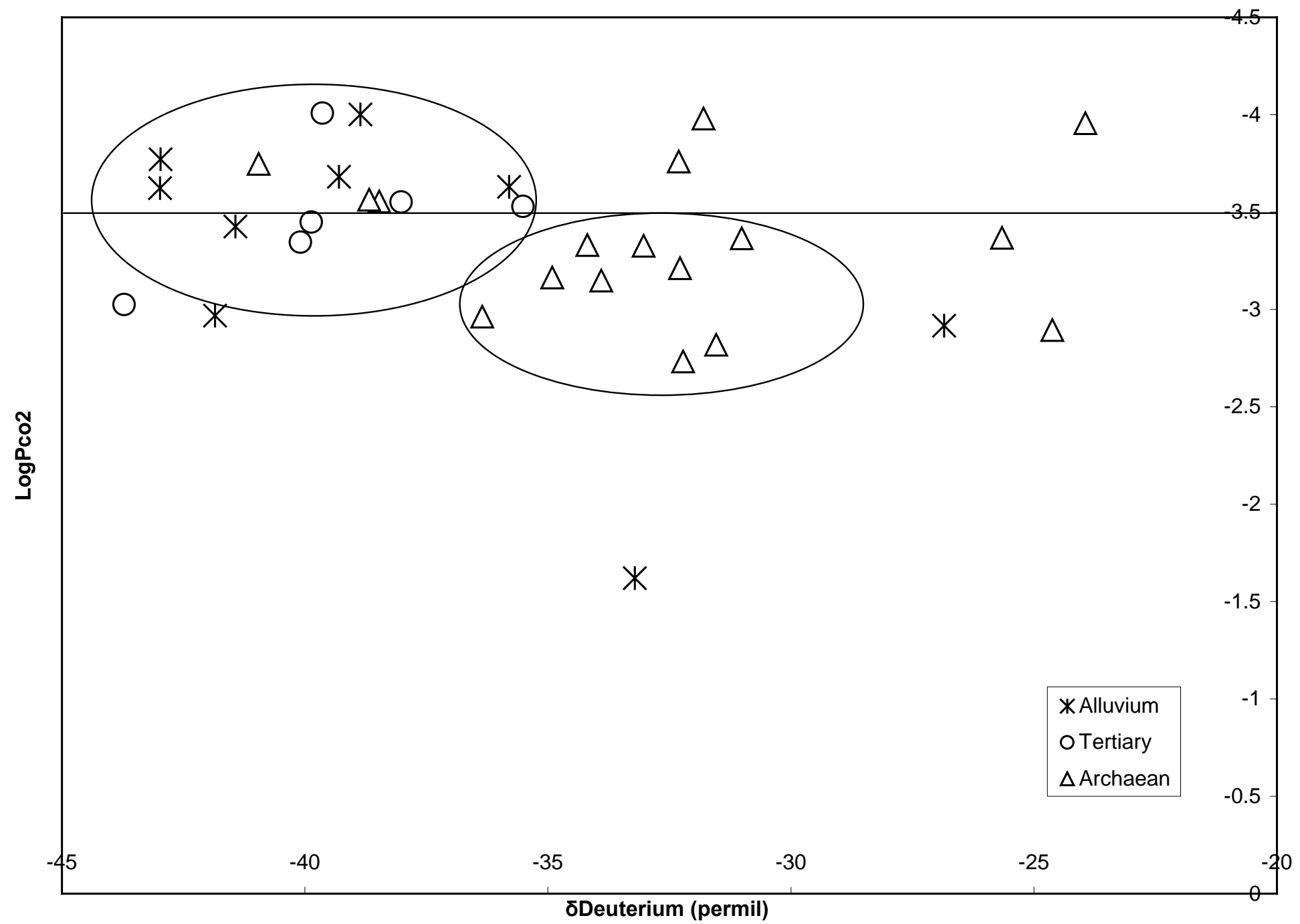

Fig. 20 Log Pco 2 Vs. $\delta D$ in POM. 


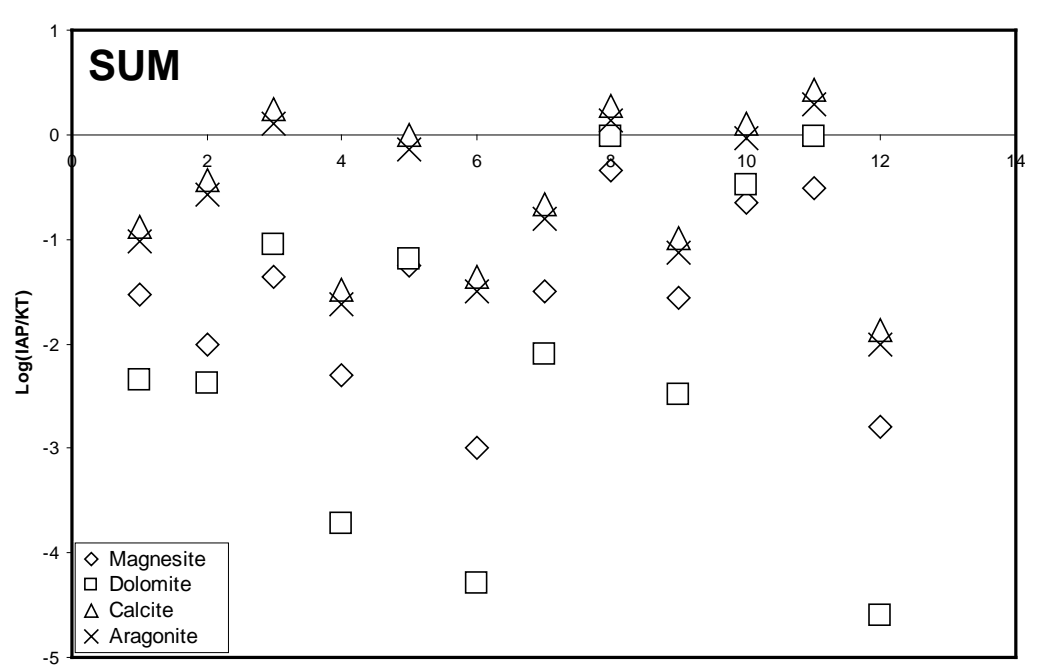

Sample №

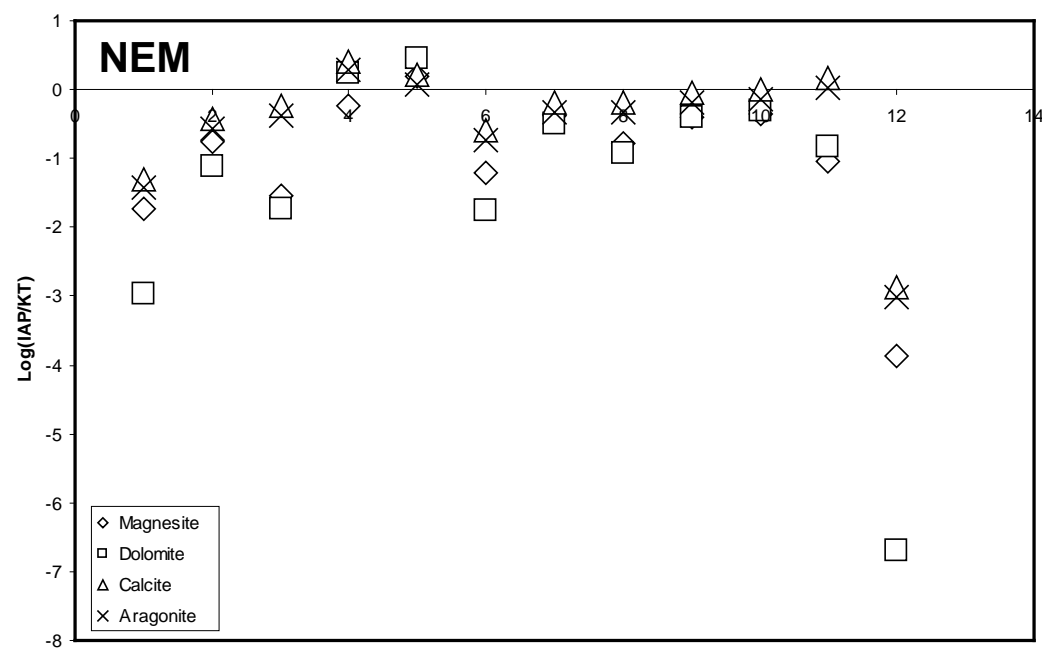

Sample
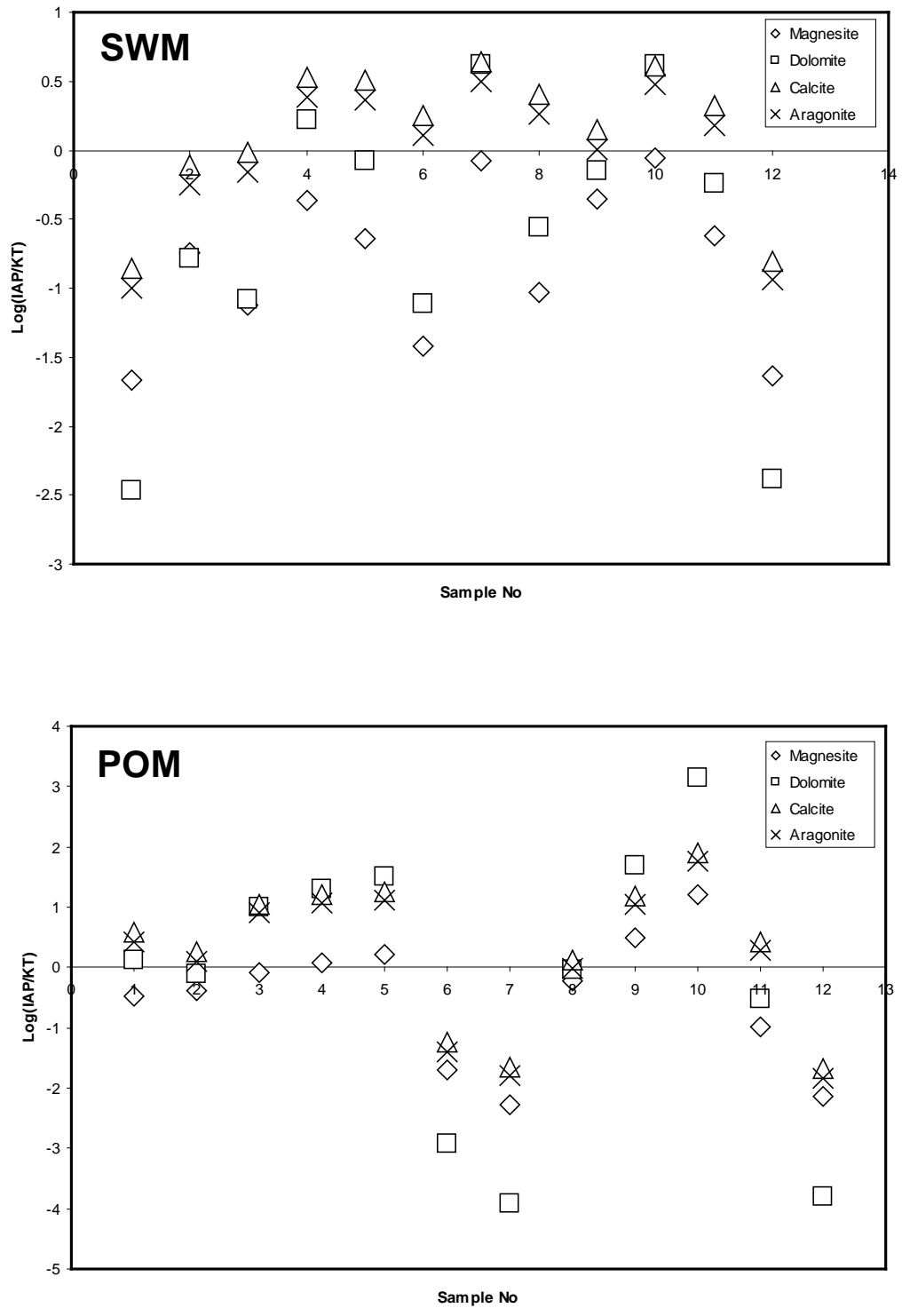

Fig. 21 Saturation Index of Carbonate minerals in Alluvium using WATEQ4F. 

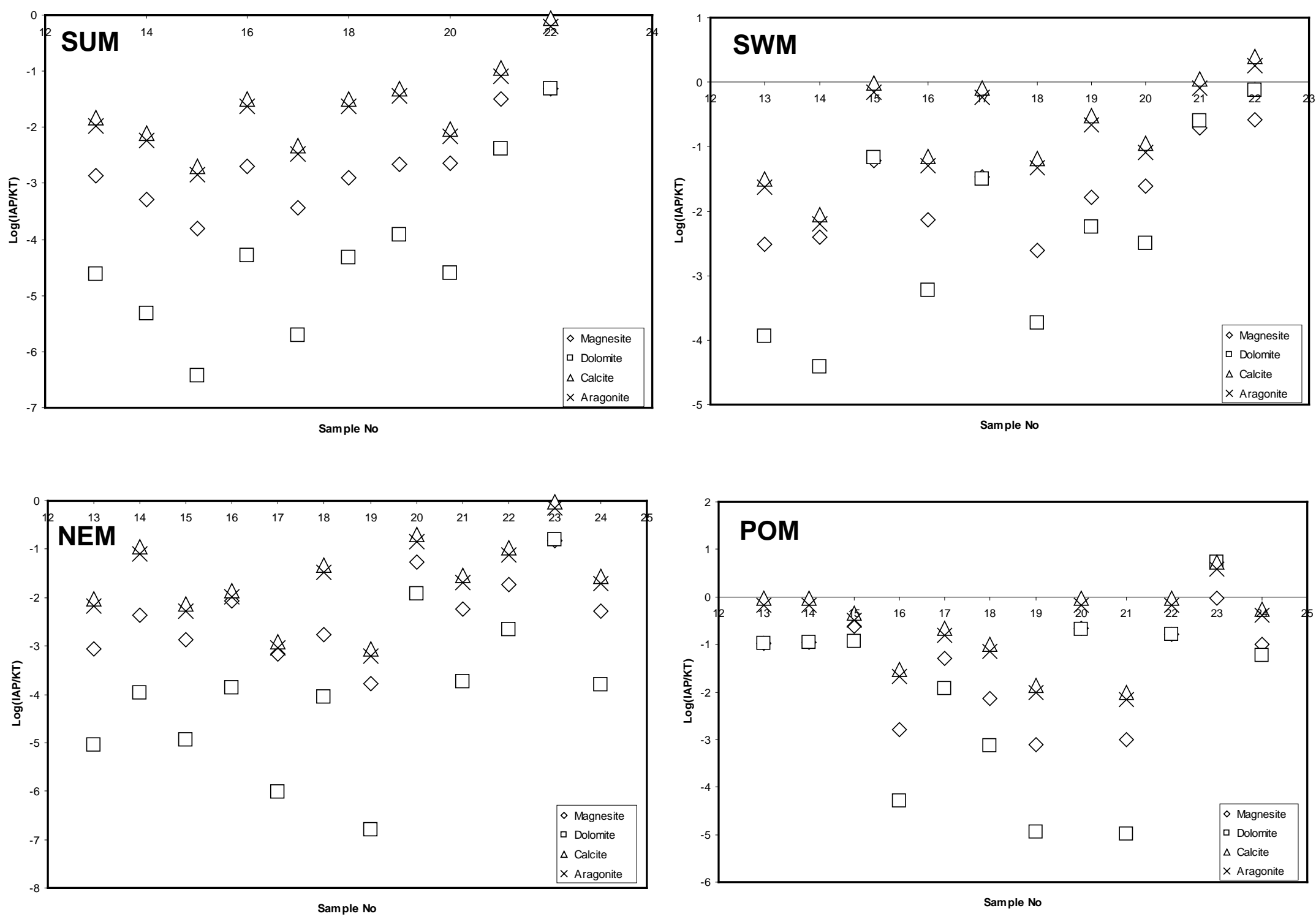

Fig. 22 Saturation Index of Carbonate minerals in Tertiary using WATEQ4F. 

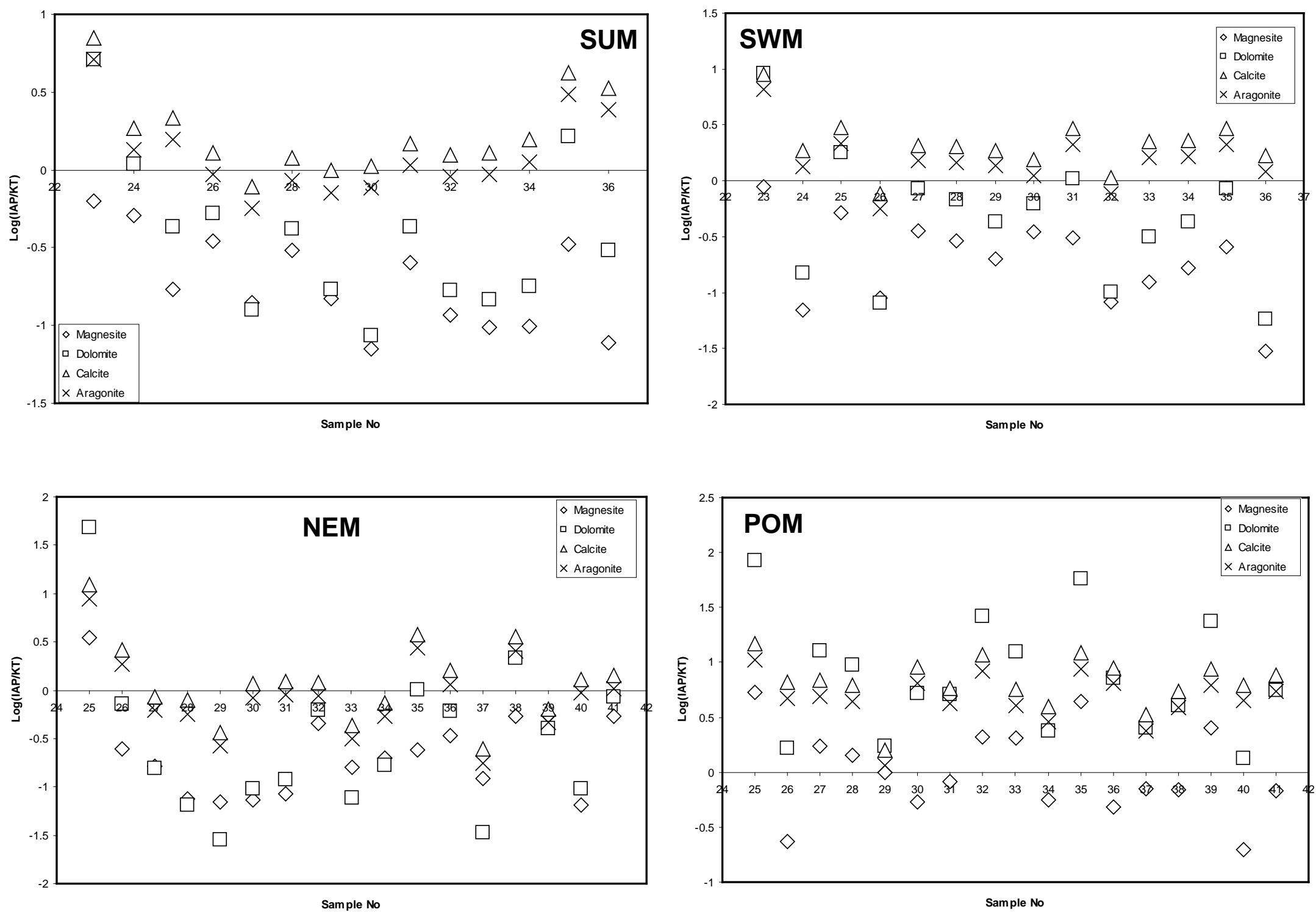

Fig. 23 Saturation Index of Carbonate minerals in Archaean using WATEQ4F. 


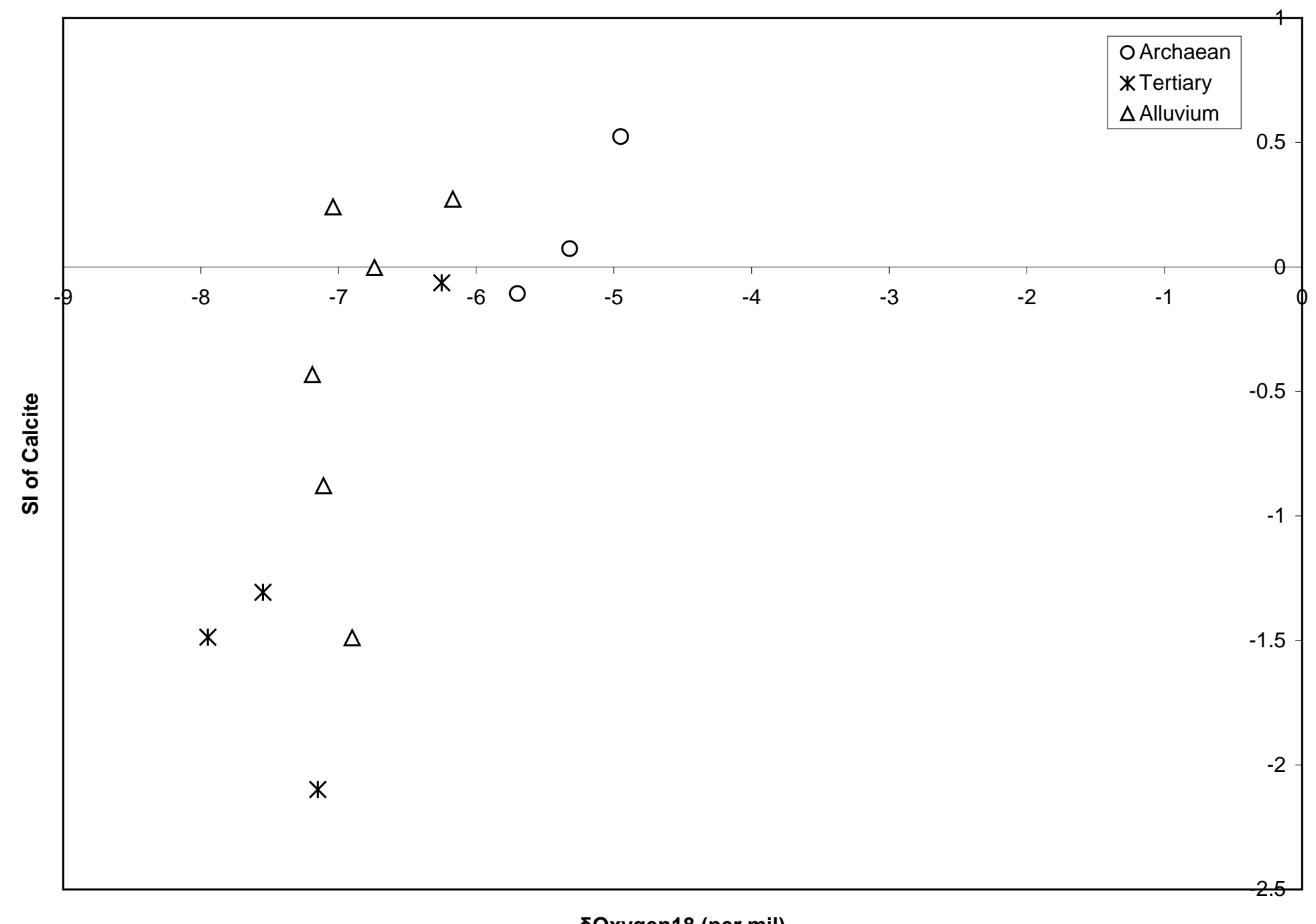

סOxygen18 (per mil)

Fig. 24 Saturation Index of Calcite Vs. $\delta^{18} \mathrm{O}$ in SWM. 


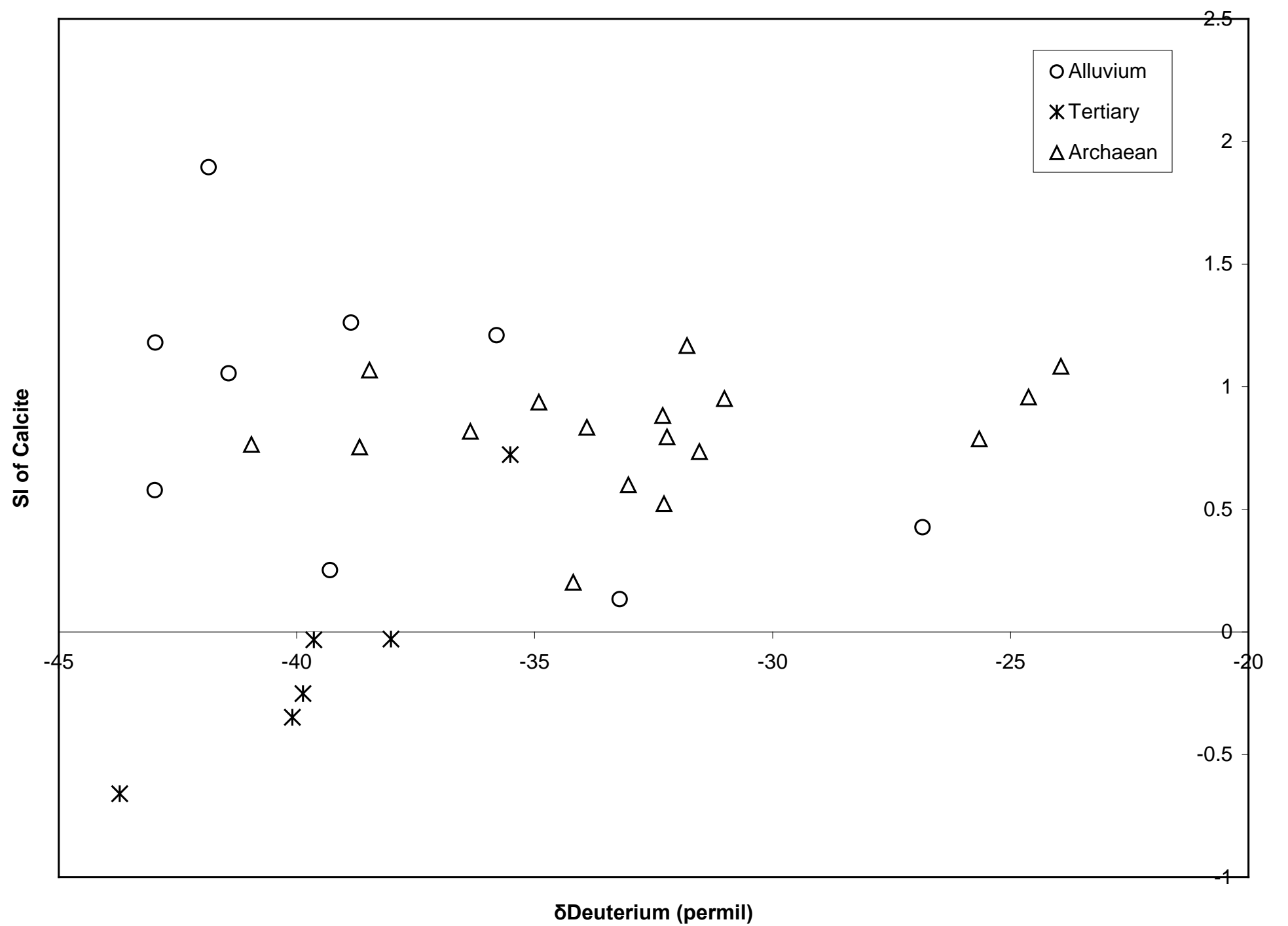

Fig. 25 Saturation Index of Calcite Vs. $\delta D$ in POM. 